\title{
Hereditary breast cancer: ever more pieces to the polygenic puzzle
}

Natalia Bogdanova ${ }^{1,2}$, Sonja Helbig ${ }^{1}$ and Thilo Dörk ${ }^{1 *}$

\begin{abstract}
Several susceptibility genes differentially impact on the lifetime risk for breast cancer. Technological advances over the past years have enabled the detection of genetic risk factors through high-throughput screening of large breast cancer case-control series. High- to intermediate penetrance alleles have now been identified in more than 20 genes involved in DNA damage signalling and repair, and more than 70 low-penetrance loci have been discovered through recent genome-wide association studies. In addition to classical germ-line mutation and single-nucleotide polymorphism, copy number variation and somatic mosaicism have been proposed as potential predisposing mechanisms. Many of the identified loci also appear to influence breast tumour characteristics such as estrogen receptor status. In this review, we briefly summarize present knowledge about breast cancer susceptibility genes and discuss their implications for risk prediction and clinical practice.
\end{abstract}

Keywords: Breast carcinoma, Germ-line mutations, Chromosomal instability

\section{Introduction}

Hereditary breast cancer has been formally investigated since the middle of the 19th century [1-3]. About thirty years ago, epidemiological and genetic linkage studies of multiple-case families have guided the identification of TP53 mutations as a cause of Li-Fraumeni Syndrome [4-6] and of BRCA1 and BRCA2 as first genes in which mutations strongly predispose to breast and ovarian cancer $[7,8]$. There are further rare syndromes which include the occurrence of breast cancer as part of the disease spectrum, and the underlying genes have been identified by positional cloning. Apart from Li-Fraumeni Syndrome, these include Cowden Disease (PTEN) $[9,10]$, Peutz-Jeghers Syndrome (LKB1/STK11) [11,12], Lynch Syndrome (MSH2,MLH1) [13], Bloom's Syndrome (BLM) [14] and Ataxia-Telangiectasia (ATM) [15]. In addition, familial lobular breast cancer has been associated with germ-line mutations in $C D H 1$, the gene for E-cadherin $[16,17]$. Although the above-mentioned syndromes are rare, they need to be kept in mind if a breast cancer patient presents with a more complex disorder or suspicious family history. For the recessive Ataxia- Telangiectasia and

\footnotetext{
* Correspondence: doerk.thilo@mh-hannover.de

${ }^{1}$ Clinics of Obstetrics and Gynaecology, Hannover Medical School, Hannover, Germany

Full list of author information is available at the end of the article
}

Bloom's Syndrome, the monoallelic occurrence of mutations predisposes heterozygous carriers outside of syndrome families to cancer, as will be described in more detail below.

While the identification of genes underlying these syndromes has been largely achieved through linkage analysis of large multiple-case pedigrees and positional cloning, these genes represent only a small subset of the estimated heritable fraction and further linkage studies have been unfruitful. However, hereditary breast cancer syndromes only mark the extreme end of a wide spectrum of genetically influenced breast carcinomas. During the past years evidence has been accumulated that breast cancer is a polygenic trait and also that several more susceptibility genes exist [18-21]. Their mutations have differential impact according to the minor allele frequencies and the magnitude of the allelic effect, which generally show an inversely proportional relationship (Figure 1) [22]. In the following, we briefly summarize present knowledge about breast cancer susceptibility genes and discuss their implications for risk prediction and clinical practice.

\section{Identification of breast cancer susceptibility alleles}

The most common methods to explore the genetic basis of hereditary breast cancer have been family and linkage studies, candidate gene sequencing and case-control

\section{Ciomed Central}




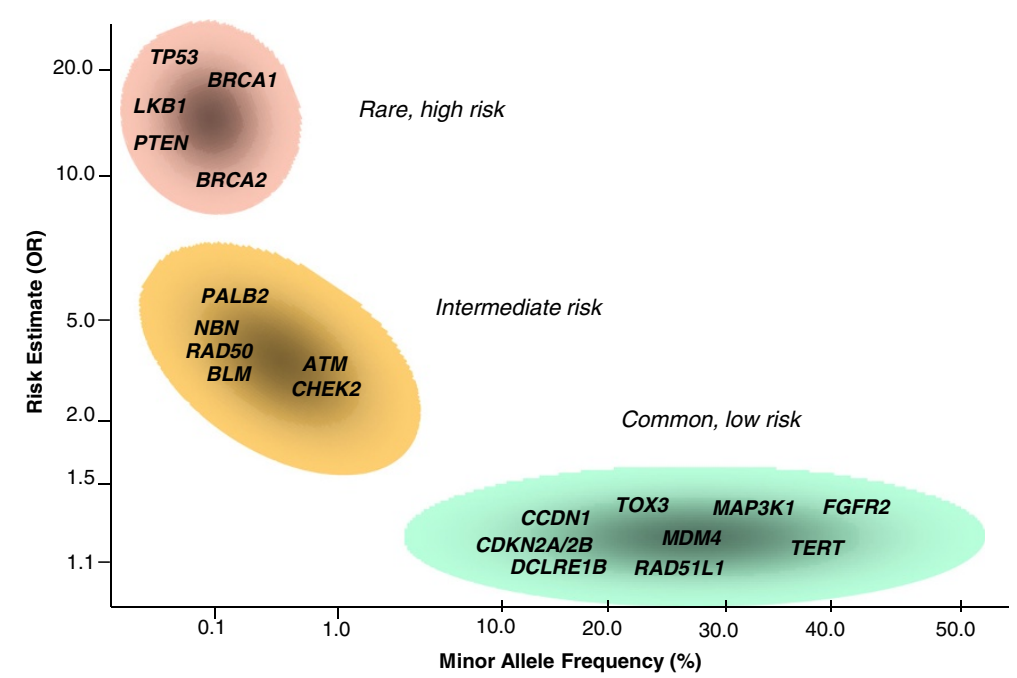

Figure 1 Frequency and risk distribution of breast cancer susceptibility alleles. Minor allele frequency of breast cancer susceptibility alleles plotted against their estimated relative risk. Selected genes are shown for high-risk, intermediate-risk and low-risk categories. Figure modified after Ref. [22].

association studies. This has led to the identification of rare mutations conferring intermediate or high risks for breast cancer (with relative risks above two-fold) as well as multiple common polymorphic loci that harbour lowpenetrance alleles.

I. Rare mutations with a high to intermediate penetrance:

Genes harbouring breast-cancer associated mutations with an estimated high or intermediate penetrance as summarised in Table 1. Many of them have turned out to encode proteins that act in concert with each other in an intracellular DNA damage signalling and repair network that responds to double-strand breaks or interstrand crosslinks and ensures the error-free damage removal through means of homology-directed recombinational repair (Figure 2). Nevertheless, lifetime risks can be quite different between the genes as will be described in more detail below.

- BRCA1 and BRCA2: The prototypic BRCA1 and $B R C A 2$ mutations confer a very high life-time risk for breast cancer in the range of $55-85 \%$ for $B R C A 1$ and $35-$ $60 \%$ for $B R C A 2$, compared with an about $10 \%$ population risk [60-62]. Life-time risk for ovarian cancer is also high and may be up to $40 \%$ for BRCA1 mutation carriers. Importantly, both the risks for breast and ovarian cancer can also be modified by additional gene loci such as SNPs in RAD51 or BNC2 (Refs. [63-65], and see below). The spectrum of tumours in families segregating $B R C A 1$ and BRCA2 mutations includes pancreatic, prostate, colon and skin cancers. Monoallelic BRCA2 mutations have also been associated with male breast cancer and have been observed in Li-Fraumeni families. Biallelic mutations in $B R C A 2$ give rise to the recessive developmental disorder, Fanconi Anemia D1 [23]. In case of BRCA1, homozygosity for severe mutations has not been confirmed and may be embryonically lethal. However, compound heterozygosity for two BRCA1 mutations, one of them apparently hypomorphic, has been described in a single patient with short stature, microcephaly and early ovarian cancer [66]. Consistent with these findings, the BRCA1 and BRCA2 genes both encode proteins involved in the repair of DNA double strand breaks [67]. While BRCA2 is mainly involved in homology-directed recombinational repair, BRCA1 may serve as a regulatory platform more upstream in assisting the signalling of breaks and the choice of repair pathways. BRCA1 is also involved in the transcriptional regulation of the estrogen and progesterone receptors. BRCA1 mutated breast cancers are usually estrogenreceptor negative and have a basal phenotype [67], while $B R C A 2$ mutated tumours exhibit a broader spectrum of phenotypes.

$B R C A 1$ and $B R C A 2$ mutations are usually truncating, although pathogenic missense mutations have also been described in crucial functional domains such as the BRCA1 RING domain. There seems to be allele-specific expressivity as some of the mutations appear to confer higher risks for ovarian cancer than others, and ovarian cluster regions have been defined for both genes [68-70]. It has also been noted that not all mutations in $B R C A 1$ and $B R C A 2$ are highly penetrant for breast or ovarian cancer. Variants such as p.R1699Q in BRCA1 or p.K3326X in $B R C A 2$ seem to be associated with rather low, though 
Table 1 Genes with intermediate to high penetrance mutations for breast cancer

\begin{tabular}{|c|c|c|c|c|}
\hline Gene & Monoallelic mutation & Biallelic mutations & Risk for breast cancer & Reference \\
\hline BRCA1 & Breast and ovarian cancer & Microcephaly and growth disorder & high & {$[7,23]$} \\
\hline$B R C A 2$ & Breast and ovarian cancer & Fanconi anemia type D1 & high & {$[8,24]$} \\
\hline TP53 & Li Fraumeni Syndrome & - & high & {$[5,6]$} \\
\hline PTEN & $\begin{array}{l}\text { PTEN harmatoma tumour syndrome } \\
\text { (Cowden Disease) }\end{array}$ & - & high & {$[9,10]$} \\
\hline LKB1 & Peutz-Jeghers Syndrome & - & high & {$[11,12]$} \\
\hline MLH1 & Lynch Syndrome & - & $\begin{array}{l}\text { probably intermediate } \\
\text { (high for endometrial and colon cancer) }\end{array}$ & [13] \\
\hline MSH2 & Lynch Syndrome/Muir-Torre Syndrome & - & $\begin{array}{l}\text { probably intermediate } \\
\text { (high for endometrial and colon cancer) }\end{array}$ & [13] \\
\hline $\mathrm{CDH} 1$ & $\begin{array}{l}\text { Lobular breast cancer, } \\
\text { diffuse gastric cancer }\end{array}$ & - & high & {$[16,17]$} \\
\hline PALB2 & Breast cancer & Fanconi anemia type $\mathrm{N}$ & intermediate to high & {$[25,26]$} \\
\hline UIMC1 & Breast cancer $^{1}$ & - & level not yet known & {$[27]$} \\
\hline FAM175A & Breast cancer $^{1}$ & - & level not yet known & {$[28]$} \\
\hline RAD51C & Breast and ovarian cancer $^{2}$ & Fanconi anemia type $\mathrm{O}$ & low to intermediate (high for ovarian cancer) & {$[29,30]$} \\
\hline RAD51D & Breast and ovarian cancer $^{2}$ & - & low to intermediate (high for ovarian cancer) & {$[31,32]$} \\
\hline BRIP1 & Breast and ovarian cancer & Fanconi anemia type J & low to intermediate (high for ovarian cancer) & {$[33,34]$} \\
\hline ATM & Breast cancer, pancreatic cancer & Ataxia telangiectasia & intermediate & {$[15,35-39]$} \\
\hline MRE11A & Breast cancer ${ }^{1}$ & Ataxia telangiectasia-like disorder & level not yet known & [40] \\
\hline$N B N$ & Breast cancer, prostate cancer & Nijmegen Breakage syndrome & intermediate & {$[41-43]$} \\
\hline RAD50 & Breast cancer & Nijmegen Breakage-like disorder & intermediate & [44] \\
\hline BLM & Breast cancer & Bloom's Syndrome & intermediate & {$[45,46]$} \\
\hline FANCC & Breast cancer $^{1}$ & Fanconi anemia type C & intermediate in FA blood relatives & {$[47,48]$} \\
\hline FANCM & Breast cancer $^{1}$ & Fanconi anemia type $\mathrm{M}$ & probably intermediate & [49] \\
\hline SLX4 & Breast cancer $^{1}$ & Fanconi anemia type $P$ & level not yet known & {$[50,51,84]$} \\
\hline$X R C C 2$ & Breast cancer $^{1}$ & - & level not yet known & {$[52,82]$} \\
\hline CHEK2 & Breast cancer,prostate cancer & breast cancer & intermediate & {$[53-58]$} \\
\hline PPM1D & Breast cancer $^{3}$, ovarian cancer ${ }^{3}$ & - & $\begin{array}{l}\text { possibly intermediate (high for ovarian cancer), } \\
\text { non-inherited }\end{array}$ & [59] \\
\hline
\end{tabular}

Legend to Table 1:

Twenty-five known or currently debated susceptibility genes harbouring intermediate or high risk mutations for breast cancer. Several of them give rise to developmental syndromes in the homozygous or compound heterozygous state as listed in the third column. The risk ranges for monoallelic mutations, as provided in column 4, are estimates for breast cancer from either family studies or case-control studies; intermediate risk 2-5, high risk > 5. ${ }^{1}$ Mutations in UIMC1, FAM175A, MRE11A, FANCC, FANCM, SLX4 and XRCC2 have been observed in very few breast cancer patients so far, therefore their possible risks are yet poorly defined. ${ }^{2}$ Mutations in RAD51C and RAD51D have been observed in breast cancer patients with a family history of ovarian cancer suggesting that they are primarily ovarian cancer susceptibility genes. ${ }^{3}$ Mutations in PPM1D are non-inherited, somatic mosaic mutations that have been reported to be associated with breast and ovarian cancer.

significant, breast cancer risks [71,72]. This indicates that, although $B R C A 1$ and $B R C A 2$ are often referred to as "high-penetrance genes", their mutational heterogeneity may produce a more diverse spectrum of allelic effects.

- PALB2: Subsequently, the "partner and localiser of BRCA2", PALB2, has been identified as another breast cancer susceptibility gene [73,74]. The PALB2 protein bridges BRCA1 and BRCA2 and synergizes in their function in recombinational DNA repair. Mutations in PALB2 predispose to breast cancer and gastric cancer, and the penetrance for breast cancer in Finnish multiple-case families has been found similarly high as for $B R C A 2$ mutations [25]. There is less evidence that $P A L B 2$ mutations predispose to ovarian cancer, although founder mutations have been identified in ovarian cancer patients from Poland and Russia [75,76]. Another founder mutation in $P A L B 2$ is recurrent in British and Australian breast cancer patients, including multiple-case families [26]. Altogether, PALB2 emerges as a third important breast cancer susceptibility gene with moderateto high penetrance mutations for breast cancer.

- UIMC1/ FAM175A/ BABAM1: The binding of BRCA1 to ubiquitylated and sumoylated histones at the site of double strand breaks is mediated by the ubiquitin- 


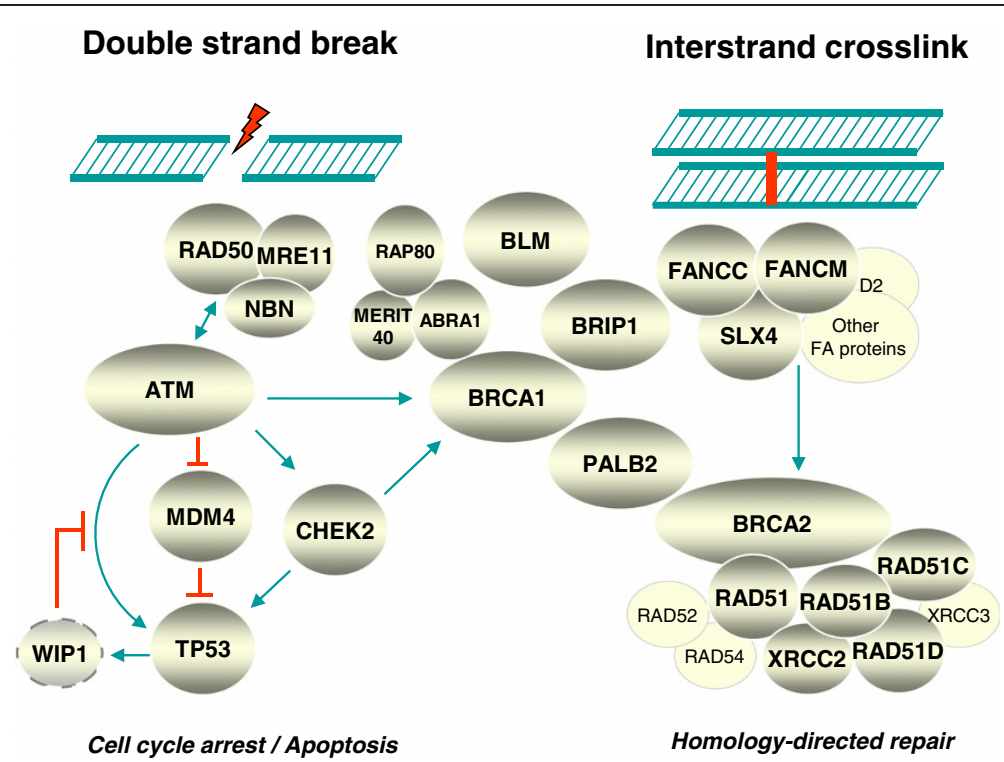

Figure 2 Network of breast cancer susceptibility proteins in DNA damage signalling and repair. Functional interplay between several known or candidate breast cancer susceptibility gene products in the intracellular response to either DNA double strand breaks (left side) or interstrand crosslinks (right side). Sensed by the Mre11-RAD50-NBN complex or by the Fanconi anemia core proteins, the respective signalling pathways merge into cell cycle arrest/apoptosis as mediated through p53, and into homology-directed recombinational repair mediated by BRCA1, PALB2, BRCA2, and the RAD51 paralogs. As mentioned in the text and in Table 1, some of the underlying genes are evidenced but have not yet been finally confirmed as bona fide breast cancer susceptibility genes, and some may mainly constitute ovarian cancer susceptibility genes. The genes for MERIT40, MDM4, and RAD51B harbour common polymorphisms associated with breast cancer, and RAD51 harbours a common SNP associated with breast cancer risk in BRCA2 mutation carriers.

interaction motif containing protein UIMC1 (better known as RAP80) through binding the FAM175A gene product ABRAXAS (also known as ABRA1 or CCDC98) that interacts with BRCA1 in a complex stabilised by MERIT40, the product of the BABAM1 gene [77]. Only few studies have addressed the role of UIMC1 or FAM175A mutations in breast cancer susceptibility. Familial breast cancer screening has revealed a rare alteration in the RAP80 UIM domain that impairs DNA damage response function [27], and an ABRAXAS mutation that disrupts nuclear localisation has been observed in breast cancer patients with mainly lobular tumour histology [28]. In addition, $B A B A M 1$ has emerged as a significant lowpenetrance risk locus for triple-negative breast cancer in genome-wide association studies as will be discussed further below.

- RAD51 paralogs: The fact that BRCA1, BRCA2 and PALB2 function together in the homology-directed recombinational repair of DNA double-strand breaks has soon prompted further investigation of candidate genes in this biological pathway. RAD51 is a key protein that mediates homologous recombination but apart from rare missense variants with uncertain significance, there have been no clearly pathogenic mutations in the coding region of the RAD51 proto-oncogene [78]. However, a regulatory variant $135 \mathrm{G} / \mathrm{C}$ in the $R A D 51$ promoter acts as a genetic modifier of BRCA2 mutations [63]. Similarly, low-penetrance variants at the RAD51L1 locus (also known as $R A D 51 B$ ) have recently been associated with breast cancer (see further below). Mutation analyses in further genes of RAD51 paralogs have uncovered RAD51C and $R A D 51 D$ as susceptibility genes in hereditary breast and ovarian cancer families [29-31]. The initial data indicated that these mutations were specifically associated with a family history of ovarian cancer and were not overrepresented in breast cancer patients outside of ovarian cancer families [29-32]. However, mutations in RAD51C and $R A D 51 D$ are collectively very rare and their risk pattern and tumour spectrum remains to be fully explored. Additional components of homologous recombinational repair complexes include RAD52, RAD54, XRCC2 and XRCC3. The RAD52 gene harbours two polymorphic stop codons which did not appear to confer a largely increased breast cancer risk, although minor risks have not been excluded $[79,80]$. A single missense variant but no clearly pathogenic mutation has been reported in RAD54 [81]. A potentially disease-causing mutation has been found in $X R C C 2$ in a recent exome sequencing study of British breast cancer patients [82]. However, follow-up studies in other European populations did not detect XRCC2 mutations indicating that these are very rare [52]. Altogether, mutations in RAD51 paralogs appear to exist at a low level in breast cancer but their contribution is small in most, if not all populations. 
- Additional Fanconi Anemia genes: Homologydirected recombinational repair complexes are a conserved repair platform that are shared by at least two convergent signalling pathways, the ATM-mediated signalling pathway triggered by DNA double-strand breaks, and the Fanconi Anemia protein pathway triggered by interstrand crosslinks. Since it had been found that some breast and ovarian cancer susceptibility alleles, e.g. in $B R C A 2$ (the FANCD1 gene), PALB2 (the FANCN gene) or $R A D 51 C$ (the FANCO gene), cause Fanconi Anemia (FA) in the homozygous state, it has been reasonable to assess further FA genes for their role in breast and ovarian cancer. So far, mutations of the BRIP1 gene have been associated with FA in the biallelic state and with breast cancer in the monoallelic state, although the risk for breast cancer appears moderate [33]. The BRIP1 protein, also known as FANCJ or BACH1, acts as a BRCA1- associated helicase, and mutations of BRIP1 also predispose to ovarian cancer with apparently higher penetrance [34]. There is less evidence implicating the FA core proteins in breast cancer [83] but exome sequencing did uncover truncating mutations of FANCC and of FANCM in single studies $[47,49]$ and rare truncating mutations have also been observed in SLX4 (the FANCP gene) $[50,51,84]$ suggesting that more FA genes might harbour rare breast cancer susceptibility alleles at a very low frequency. Their penetrance is unknown, however, the difficulties to confirm very early reports of an increased breast cancer risk in obligate heterozygotes from FA families may indicate that the risks are genetically heterogeneous and moderate on average, with a possible preponderance of FANCC [48].

- ATM: It has been known for long that blood relatives of patients with the neurodegenerative disorder AtaxiaTelangiectasia (A-T) face an increased breast cancer risk [35]. Homozygous A-T patients usually do not survive into late adulthood, but a few females with attenuated A-T have been reported to develop bilateral breast cancer [15]. The gene mutated in Ataxia-Telangiectasia, $A T M$, encodes a master protein kinase that orchestrates the cellular response to DNA double-strand breaks and controls via phosphorylation hundreds of proteins involved in cell cycle control, repair and apoptosis, among them BRCA1, BRCA2, BLM, TP53, CHEK2 and many other tumour suppressors [36]. Truncating mutations in ATM appear to confer an about three-fold increased breast cancer risk to heterozygous carriers [37-39], and heterozygotes may account for $0 \cdot 5-1 \%$ of most populations.

- MRE11A/ RAD50/NBN: At the early steps of DNA double strand break signalling, chromosome breaks are sensed and the ATM protein is activated via the MRN complex consisting of the proteins MRE11A, RAD50, and NBN [85]. The NBN gene underlies Nijmegen Breakage Syndrome (NBS), which is most prevalent in
Eastern Europe due to a Slavic founder mutation [86]. While biallelic mutations cause NBS, a cancer-prone developmental condition with early mortality, heterozygous carriers face an about 3-5 fold increased breast cancer risk [41-43]. Similarly, biallelic mutations in RAD50 give rise to a NBS-like disorder whereas heterozygotes for a Finnish founder mutation are predisposed towards breast cancer [44,87]. MRE11A also is a gene for an A-T like disorder though there has been only one study to associate MRE11A mutations with breast cancer so far $[40,88]$. Germ-line mutations in either of the three genes were also identified in an ovarian cancer sequencing study [89]. Thus, similar to the Fanconi anemia proteins, several components of DNA double strand break sensing complexes seem to be target of germ-line mutations in breast and ovarian cancer susceptibility.

- BLM: Another such gene that has recently been implicated in breast cancer susceptibility, is $B L M$, the gene mutated in Bloom's Syndrome [90]. Bloom's Syndrome (BS) is an autosomal recessive syndrome associated with short stature, premature aging and a high propensity to develop malignancies including breast cancer [14]. Cells from BS patients exhibit enhanced levels of sister chromatid exchanges, which reflects a hyperrecombinational phenotype as a consequence of $B L M$ mutations and dysfunction of the encoded RecQ-type DNA helicase. A nonsense mutation in $B L M$, initially been observed in few BS patients, has been associated with breast cancer in Slavic populations, and the presently available evidence for BS mutations indicates an approximately 2-5 fold increase in breast cancer risk for heterozygotes [45,46,91].

- CHEK2: One of the major targets of the ATM kinase is CHEK2 which itself phosphorylates further tumour suppressor proteins, including p53 and BRCA1, in response to DNA damage [92]. CHEK2 had initially been found mutated in Li-Fraumeni patients and one of these mutations, c.1100delC, has subsequently been associated with familial breast cancer $[53,54]$. Heterozygous carriers have been reported with a 2-3 fold increase in breast cancer risk, with rare homozygotes being found at a much higher risk $[55,56]$. In Eastern Europe, two further truncating mutations have been associated with at least similarly high breast cancer risks, whereas a missense mutation, p.I157T, has a lower penetrance $[41,57,58]$. There has also been some evidence for an association of CHEK2 mutations with ovarian cancer and for additional malignancies suggesting a more general role in cancer predisposition $[89,93]$. It is interesting to note that, although CHEK2 interacts with BRCA1 in the same pathway, its mutations are significantly associated with estrogen receptor positive breast tumours, indicating an impact on tumour etiology that is different from BRCA1.

- PPM1D: Large-scale sequencing has identified truncating mutations in the p53-inducible protein 
phosphatase PPM1D which were specifically associated with breast cancer and ovarian cancer [59]. PPM1D encodes the oncogenic phosphatase WIP1 that antagonizes ATM-mediated p53 phosphorylation. By contrast with the other genes discussed above, all of the identified PPM1D mutations were mosaic in lymphocyte DNA and, where tested, were not observed in breast or ovarian tissue, suggesting a late origin in the germ-line. Their mechanism of action in breast or ovarian cancer development is presently unknown. Somatic mosaicism has previously been observed for TP53 mutations outside of Li-Fraumeni families [89] suggesting that, in addition to classical heritable genetic factors, mosaic mutations may also contribute to the genetic predisposition to breast and ovarian cancer. These observations, if confirmed, could have important consequences for mutational screening as well as counselling. Certainly, the origin and frequency of mosaic mutations need to be studied in more detail before final conclusions can be derived.

\section{Polymorphic variants with low penetrance:}

Beyond the genes with relatively rare mutations discussed above, common polymorphisms have been predicted to significantly impact on risk and prevention if breast cancer were regarded as a polygenic disease [94]. Several polymorphic loci are meanwhile known which influence the risk of breast cancer (Table 2). This has been mainly achieved through genome-wide association studies (GWAS) of single nucleotide polymorphism by large consortia during the past six years. The published GWAS efforts have uncovered over 70 genomic loci for breast cancer at a genome-wide significance level [72,95-118]. All these loci harbour low-penetrance alleles with allelic odds ratios less than $1 \cdot 5$. Apart from a coding variant in DCLRE1B (the gene for the SNM1B/Apollo protein involved in DNA cross-link repair) and synonymous variants in BABAM1 and TERT, the majority of identified variants are either intronic or intergenic. The observed intronic and intergenic variants may affect genomic regions important for the regulation of gene expression and/or gene function. As these loci still explain only a small part of the heritable fraction, it is likely that the numbers will increase rapidly. Presently known GWAS loci now cover approximately $15 \%$ of the familial relative risk, compared to about $21 \%$ captured by moderate- to high penetrance alleles. But evidence suggests that several hundreds of low-penetrance breast cancer loci might exist, meaning that even with the numbers reached so far, studies have merely grazed the surface of the iceberg [72].

Many of the identified GWAS loci appear to be specific for breast carcinomas. For example, the gene for fibroblast growth factor receptor 2, FGFR2, harbours variants associated with breast but not ovarian cancer
$[95,96]$ and breast cancer-associated variants in this gene appear to regulate the transcriptional activation of FGFR2 in an estrogen-dependent manner [131]. The interaction with estrogen signalling may also explain why the association of some variants is restricted to ER-positive breast carcinomas (Table 2). Several of the GWAS loci further modify the risk for $B R C A 1$ or $B R C A 2$ mutation carriers [132]. In some instances, variants have been observed to differentially associate with breast cancer risk in $B R C A 1$ or $B R C A 2$ carriers, and one variant has been reported to specifically associate with BRCA2 mutations [118]. Additionally, variants at the RAD51L1 and TOX3 loci have independently been identified in a GWAS for male breast cancer [111].

A minor group of common susceptibility loci has turned out to be relevant for other common cancers as well, perhaps due to their general relevance for genome integrity [133]. Some loci appear to influence both breast and ovarian cancer risk such as BABAM1, TERT, and the protooncogene $M Y C$ on chromosome 8q24. Variants at the $B A B A M 1$ locus, encoding a BRCA1 binding partner also known as MERIT40, have been specifically associated with triple-negative breast cancer and serous epithelial ovarian cancer, which resembles the picture seen with BRCA1 mutations [102,134]. A closer inspection of the TERT locus, encoding a component of telomerase, has uncovered three independent regions of strong association with breast or ovarian cancer that only partially overlap and appear to act through different mechanisms of transcriptional regulation or splicing, respectively [114]. Similarly, a closer inspection of the 8q24 locus upstream of $M Y C$ has indicated that the associations with different cancers were caused by independent variants at the same locus, possibly explained by tissue-specific regulation of gene expression through long-distance effects of enhancer regions [135]. These findings illustrate that, in several instances, low-penetrance breast cancer susceptibility alleles may exert regulatory roles in the fine-tuning of gene expression in the respective tissue, and the patterns of regulation can be complex.

As a caveat, a GWAS roughly localises but usually does not yet identify the causal variant. In several cases there is more than one candidate gene in the region spanned by the associated LD block, and there can be even more candidate genes under putative regulatory control of the identified locus. For example at the 5 q11.2 locus, the MAP3K1 gene represents an excellent candidate as it represents one of the most frequently mutated genes in breast tumours but MIER3 is another mammary tumour suppressor gene nearby $[136,137]$. In some instances, available microarray data supported an association of the identified SNP with gene expression [72,138]. One locus, $L S P 1$, lies in proximity to the imprinted region $H 19 / I G F 2$, and breast cancer risk has been reported to be 
Table 2 Genomic loci harbouring low-penetrance breast cancer susceptibility alleles

\begin{tabular}{|c|c|c|c|c|c|}
\hline Locus & SNP & $\begin{array}{l}\text { Reported } \\
\text { gene }\end{array}$ & Nearby genes (selected) & $\begin{array}{l}\text { Association with } \\
\text { ER status }\end{array}$ & Reference \\
\hline $1 p 11$ & rs2580520, rs11249433 & EMBP1 & HIST3, HIST2H2BA & $E R+v e \sim E R-v e$ & {$[99,101,119,120]$} \\
\hline $1 \mathrm{p} 13$ & rs11552449 & DCLREIB & PTPN22, HIPK1, BCL2L15 & $E R+v e>E R-v e$ & [72] \\
\hline $1 \mathrm{p} 36$ & rs616488 & PEX14 & $K I F 1 B, U B E 4 B, R B P 7$ & $E R-v e>E R+v e$ & [37] \\
\hline $1 q 32$ & rs4245739 & MDM4 & PIK3C2B & ER-ve & [115] \\
\hline $1 q 32$ & rs6678914 & LGR6 & UBE2T, PTPN7 & ER-ve & [115] \\
\hline $2 \mathrm{p} 24$ & rs12710696 & intergenic & OSR1 & ER-ve & [115] \\
\hline $2 q 14$ & rs4849887 & intergenic & INHBB, RALB, GLI2 & $E R+v e \sim E R-v e$ & [72] \\
\hline $2 q 31$ & rs2016394 & intergenic & $D L X 1, D L X 2, I T G A 6, P D K 1$ & $E R+v e$ & [72] \\
\hline $2 q 31$ & rs1550623 & intergenic & CDCA7, MLKT-AS1, ZAK & $\mathrm{ER}+\mathrm{ve} \sim \mathrm{ER}-\mathrm{ve}$ & [72] \\
\hline $2 q 33$ & $\begin{array}{l}\text { rs1045485, rs10931936, rs3834129- } \\
\text { rs6723097-rs3817578 }\end{array}$ & CASP8 & CASP10, ORC2, CDK15 & $E R+v e \sim E R-v e$ & {$[101,121,122]$} \\
\hline $2 q 34$ & rs13393577 & ERBB4 & MIR4776 & $E R+v e \sim E R-v e$ & [110] \\
\hline $2 q 35$ & rs13387042, rs16857609 & DIRC3 & PINC, TNS1, IGFBP1, IGFBP5 & $E R+v e>E R-v e$ & {$[72,97,103,123,124]$} \\
\hline $3 p 24$ & rs4973768 & SLCAA7 & NEK10 & $E R+v e>E R-v e$ & {$[98,101,103]$} \\
\hline $3 p 24$ & rs12493607 & TGFBR2 & GADL1 & $E R+v e$ & [72] \\
\hline $3 p 26$ & rs10510333 & intergenic & GRM7 & $E R+v e \sim E R-v e$ & [113] \\
\hline $3 p 26$ & rs6762644 & ITPR1 & SUMF1, BHLHE4O & $E R+v e$ & [72] \\
\hline $3 q 25$ & rs6788895 & $\mathrm{SIAH} 2$ & MED12L, SELT, EIF2A & $E R+v e$ & [112] \\
\hline $3 q 26$ & rs3806685 & intergenic & PIK3CA, ZNF639 & $E R+v e \sim E R-v e$ & [110] \\
\hline $4 q 24$ & rs9790517 & TET2 & PPA2 & $E R+v e$ & [72] \\
\hline $4 q 34$ & rs6828523 & ADAM29 & GLRA3 & $E R+v e$ & [72] \\
\hline $5 q 11$ & rs889312, rs16886165 & intergenic & MAP3K1, MIER3 & $E R+v e>E R-v e$ & {$[95,99,101]$} \\
\hline $5 q 11$ & rs1353747, rs10472076 & PDE4D & RAB3C, PDK2 & $E R+v e \sim E R-v e$ & [72] \\
\hline $5 p 12$ & $\begin{array}{l}\text { rs } 4415084, \text { rs } 10941679, \text { rs7716600, } \\
\text { rs9790879, rs4866929 }\end{array}$ & intergenic & HCN1, MRPS30,FGF10 & $E R+v e>E R-v e$ & {$[96,97,101,103,124]$} \\
\hline $5 p 15$ & rs1092913 & intergenic & $M A R C H 6, D A P$ & $E R+v e>E R-v e$ & {$[105,110]$} \\
\hline $5 p 15$ & rs2736108, rs10069690, rs2242652 & TERT & CLPTMTL & variant specific & {$[104,114]$} \\
\hline $5 q 33$ & rs1432679 & EBF1 & RNF145, UBLCP1 & $\mathrm{ER}+\mathrm{ve} \sim \mathrm{ER}-\mathrm{ve}$ & [72] \\
\hline $6 \mathrm{p} 23$ & rs204247 & intergenic & RANBP9, SIRT5, CCDC90A & $E R+v e$ & [72] \\
\hline $6 \mathrm{p} 24$ & rs9348512 & intergenic & GCNT2, PAK1IP1, TFAP2A & $B R C A 2$ specific & [118] \\
\hline $6 \mathrm{p} 25$ & rs11242675 & intergenic & FOXQ1, FOXF2, FOXC1 & $E R+v e \sim E R-v e$ & [72] \\
\hline $6 q 14$ & rs17529111, rs17530068 & intergenic & FAM46A, IBTK, SSBP2 & $E R+v e \sim E R-v e$ & {$[72,109]$} \\
\hline $6 q 25$ & rs9498283 & TAB2 & SUMO4, LATS1 & $\mathrm{ER}+\mathrm{ve} \sim \mathrm{ER}$-ve & [110] \\
\hline $6 q 25$ & $\begin{array}{l}\text { rs3757318, rs12662670, rs6929137, } \\
\text { rs3734804, rs3734805, rs2046210 }\end{array}$ & intergenic & ESR1 & variant specific & {$[100,101,103,106,125-127]$} \\
\hline $7 q 32$ & rs2048672 & FL 43663 & MIR29A, KLF14 & not mentioned & [106] \\
\hline $7 q 35$ & rs720475 & ARHGEF5 & NOBOX & $E R+v e$ & [72] \\
\hline $8 p 12$ & rs9693444 & intergenic & DUSP4, KIF13B & $E R+v e \sim E R-v e$ & [72] \\
\hline $8 q 21$ & rs6472903, rs2943559 & HNF4G & CRISPLD1, ZFHX4 & $E R+v e>E R-v e$ & {$[72]$} \\
\hline $8 q 24$ & $\begin{array}{l}\text { rs672888, rs1562430, } \\
\text { rs13281615, rs11780156 }\end{array}$ & intergenic & PVT1, MIR1204-08, MYC & $\mathrm{ER}+\mathrm{ve} \sim \mathrm{ER}-\mathrm{ve}$ & {$[72,95,101,103]$} \\
\hline $9 p 21$ & rs1011970 & $C D K N 2 B$ & CDKN2A, CDKN2B-AS1 & $E R+v e>E R-v e$ & [101] \\
\hline $9 q 31$ & rs865686, rs10759243 & intergenic & RAD23B, KLF4 & $E R+v e>E R-v e$ & {$[72,103]$} \\
\hline 10p12 & rs7072776, rs1 1814448 & intergenic & DNAJC1, MLLT10 & $E R+v e \neq E R-v e$ & [72] \\
\hline 10p15 & rs2380205 & intergenic & ANKRD16, FBXO18, GDI2 & $E R+v e \sim E R-v e$ & [101] \\
\hline
\end{tabular}


Table 2 Genomic loci harbouring low-penetrance breast cancer susceptibility alleles (Continued)

\begin{tabular}{|c|c|c|c|c|c|}
\hline $10 q 21$ & rs10822013, rs10995190 & ZNF365 & EGR2, NRBF2 & $E R+v e>E R-v e$ & {$[101,106]$} \\
\hline $10 q 22$ & rs704010, rs12355688 & ZMIZ1 & PPIF, ZCCHC24, EIF5AL1 & $E R+v e \sim E R-v e$ & {$[101,113]$} \\
\hline $10 q 25$ & rs7904519 & TCF7L2 & ZDHHC6, CASP7, DCLRETA & $E R+v e \sim E R-v e$ & {$[72]$} \\
\hline $10 q 26$ & $\begin{array}{l}\text { rs2981582, rs11199914, rs2981579, } \\
\text { rs1219648, rs10510102 }\end{array}$ & FGFR2 & WDR11, TACC2 & $E R+v e$ & {$[72,95,96,99,101,103,124]$} \\
\hline $11 \mathrm{p} 15$ & rs3817198, rs909116 & LSP1-TNNT3 & CTSD, DUSP8, IGF2 & $E R+v e \sim E R-v e$ & {$[95,101,128]$} \\
\hline $11 q 13$ & rs3903072 & intergenic & RELA, MAP3K11, MUS81 & $E R+v e$ & {$[72]$} \\
\hline $11 q 13$ & $\begin{array}{l}\text { rs614367, rs661204, rs78540526, } \\
\text { rs554219, rs657686, rs75915166 }\end{array}$ & intergenic & CCND1, FGF19, FGF4, FGF3 & $E R+v e>E R-v e$ & {$[101,116]$} \\
\hline $11 q 24$ & rs11820646 & intergenic & BARX2, NFRKB, PRDM10 & $E R+v e \sim E R-v e$ & [72] \\
\hline $12 p 11$ & rs10771399 & PTHLH & CCDC81 & $E R+v e \sim E R-v e$ & [108] \\
\hline $12 p 13$ & rs12422552 & intergenic & ATFIIP, GRIN2B, PLBD1 & $\mathrm{ER}+\mathrm{ve} \sim \mathrm{ER}$-ve & [72] \\
\hline $12 q 22$ & rs17356907 & intergenic & $\begin{array}{l}\text { NTN4, USP44, METAP2, } \\
\text { NR2C1 VEZT, FGD6, CCDC38 }\end{array}$ & $E R+v e \sim E R-v e$ & {$[72]$} \\
\hline $12 q 24$ & rs1292011 & intergenic & TBX3 & $E R+v e>E R-v e$ & [108] \\
\hline $14 q 13$ & rs2236007 & PAX9 & $N K X 2-8$ & $E R+v e>E R-v e$ & {$[72]$} \\
\hline $14 q 24$ & $\begin{array}{l}\text { rs999737, rs2588809, rs1314913, } \\
\text { rs10483813, rs8009944, }\end{array}$ & RAD51B & ZFP36, ACTN1, DCAF5 & $E R+v e$ & {$[72,99,101,111,119]$} \\
\hline $14 q 31$ & rs4322600 & GALC & GPR65 & $E R+v e \sim E R-v e$ & [113] \\
\hline $14 q 32$ & rs941764 & CCDC88C & $\begin{array}{l}\text { GPR68, SNORA11B, RPS6KA5, } \\
\text { SMEK1, CATSPERB, TC2N }\end{array}$ & $E R+v e$ & [72] \\
\hline $16 q 12$ & rs3803662 & intergenic & TNRC9/TOX3, MIR548, CHD9 & $E R+v e>E R-v e$ & {$[95,101,103,107,111,124]$} \\
\hline $16 q 12$ & rs17817449, rs11075995 & FTO & AKTIP, RBL2, CHD9 & $\mathrm{ER}+\mathrm{ve} \sim \mathrm{ER}-\mathrm{ve}$ & {$[72,115]$} \\
\hline $16 q 23$ & rs13329835 & CDYL2 & CENPN, ATMIN, GCSH, PKDIL2 & $E R+v e>E R-v e$ & {$[72]$} \\
\hline $17 q 22$ & rs6504950, rs1156287 & STXBP4 & COX11, HLF & $E R+v e>E R-v e$ & {$[98,101]$} \\
\hline $17 q 24$ & rs11077488 & intergenic & KCNJ2, KCNJ16 & Not mentioned & [110] \\
\hline $18 q 11$ & rs527616, rs1436904 & CHST9 & KCTD1, TAF4B & $E R+v e>E R-v e$ & {$[72]$} \\
\hline $19 p 13$ & rs8170, rs8100241, rs2363956 & BABAM1 & ANKLE1 & ER-ve & {$[102,109,129]$} \\
\hline $19 p 13$ & rs4808801 & ELL & SSBP4, FKBP8, PDE4C & $E R+v e \sim E R-v e$ & {$[72]$} \\
\hline $19 q 13$ & rs3760982 & intergenic & ZNF Cluster, KCNN4, SMG9, XRCC1 & $E R+v e \sim E R-v e$ & [72] \\
\hline $19 q 13$ & rs10411161, rs3848562 & ZNF577 & MIR125A, ZNF Cluster & Not mentioned & [105] \\
\hline $20 q 11$ & rs2284378 & RALY & ASIP, EIF2S2, CHMP4B, ZNF341, E2F1 & ER-ve & [109] \\
\hline $21 q 21$ & rs2823093 & intergenic & NRIP1 & $E R+v e>E R-v e$ & [108] \\
\hline $22 q 12$ & rs132390 & EMID1 & KREMEN1, CHEK2, EWSR1, NF2 & $E R+v e \sim E R-v e$ & {$[72]$} \\
\hline $22 q 13$ & rs6001930 & MKL1 & $\begin{array}{l}\text { SGSM3, ADSL, MCHR1, XPNPEP3, } \\
\text { DNAJB7, RBX1 }\end{array}$ & $E R+v e \sim E R-v e$ & [72] \\
\hline $22 q 13$ & CNV2576, tagged by rs 12628403 & $\begin{array}{l}A P O B E C 3 A- \\
A P O B E C 3 B\end{array}$ & APOBEC $3 C$ & $\mathrm{ER}+\mathrm{ve} \sim \mathrm{ER}$-ve & [130] \\
\hline
\end{tabular}

Legend to Table 2:

72 genomic loci that have been found to harbour low-penetrance breast cancer susceptibility alleles. Genes already mentioned in Table 1 have been excluded although long-range effects remain a possibility. All loci except for CASP8 have been derived from genome-wide association studies. Some chromosomal loci that harbour more than one independent risk variant were here combined when there was a strong overlap of candidate genes. If the variant was within a gene, this is listed separately, although this does not necessarily mean it represents the causal gene. Selected candidate genes in the vicinity $(<1 \mathrm{Mb})$ are listed in the fourth column. Genes were taken from the GRCh37.p10 primary assembly drawn from the NCBI Genbank (http://www.ncbi.nlm.nih.gov/gene). Association with ER status has been drawn from the original references, and a preponderance of one subtype was assumed if $p$ (het) $<0.05$. Note that genome-wide significance has been borderline for some results $[106,110,113]$ so that additional validation may be needed for those variants.

limited to the paternally inherited allele [128]. In other instances, identified loci have independently been correlated with previously known risk factors for breast cancer, such as FTO for obesity, INHBB for breast size or ZNF365 for mammographic density, strongly suggesting that the risk for breast cancer could be mediated via these physiological traits [139-142]. But for the majority of loci, fine-mapping approaches in different ethnic populations as well as gene 
expression and chromatin configuration studies are presently being used to further trace down the true predisposing variants. A combination of such approaches has recently identified regulatory mechanisms that underlie the association of independent variants at 11q13 with breast cancer and act in concert to orchestrate cyclin D1 expression [116].

Copy number variants (CNVs) have also been investigated at a genome-wide level. While one GWAS did not detect a significant association for breast cancer in European patients another one detected a significant association with a common $A P O B E C 3 B$ deletion in Chinese breast cancer patients [130,143]. APOBEC $3 B$ encodes a cytosine deaminase that functions in localised hypermutation ("kataegis") and may be responsible for chronic DNA damage in breast cancers $[144,145]$. Loss of one or both $A P O B E C 3 B$ copies was associated with odds ratios of $1 \cdot 31$ and $1 \cdot 76$, respectively [130]. Additional recent studies also showed a consistent increase in the frequency of rare CNVs in breast cancer cases when compared to controls $[146,147]$, with a particular enrichment of CNVs in genes involved in estrogen signalling and DNA double strand break repair in one study [147]. If confirmed, this mirrors some results from genome-wide SNP analyses, although there has been no overlap of the identified loci thus far.

\section{Implications for risk prediction and therapy}

Hereditary breast cancer represents a challenge in terms of genetic counselling as well as preventive and therapeutic decisions. The identification of mutations in individuals from multiple-case families with breast cancer makes it possible to predict the age-dependent risk for different cancers, including recurrence risks in the already affected, and to counsel patient and blood relatives more appropriately. With the identification of modifying variants, the risk prediction for $B R C A 1$ or $B R C A 2$ mutation carriers can be further refined. Risk prediction may lead to an increased surveillance or targeted prevention including magnetic resonance imaging, medication (such as tamoxifen) or preventive surgery (such as prophylactic oophorectomy). In many countries, this is available to patients with a high (over $30 \%)$ lifetime risk such as $B R C A 1$ or $B R C A 2$ mutation carriers, whereas a more restrained position is taken for patients with intermediate-penetrance mutations conferring an about 3-fold increase in breast cancer risk such as $A T M$ or CHEK2. Although the female carriers for those mutations could also benefit from increased surveillance, large studies on the efficacy of such measures are lacking. No further counselling is provided for patients carrying common risk alleles at polymorphic loci, as these risks are too small individually to be clinically meaningful. This situation may change, however, if one considers cumulative effects for several of those variants that can reach substantial risk modifications already at the present stage of knowledge. Previous estimates predicted that half of the population at highest risk may account for about $88 \%$ of breast cancer cases [94]. Using the current set of loci and assuming that all loci combine multiplicatively, risks of breast cancer were estimated approximately $2 \cdot 3$-fold and 3 -fold higher for individuals in the top $5 \%$ and $1 \%$ of the population, relative to the population average [72]. With the identification of many more low-risk loci it may become possible to calculate combinatorial risks that could be useful in a stratified approach of cancer prevention in the future [148-150].

Population diversity needs to be taken into account for breast cancer susceptibility at all levels of penetrance. Due to founder effects, single mutations can contribute significantly to the breast cancer burden in founder populations and intermediate-risk alleles in some genes have almost exclusively been found in certain population groups, such as for FAM175A and RAD50 in the Finnish population or $N B N$ in Slavic populations [28,41-44]. In fact, much of the present knowledge about those genes relies on particular founder mutations, and in regard of allelic heterogeneity one must be cautious to extrapolate and generalise these observations to other less common alleles. Similarly, common polymorphisms at breast cancer susceptibility loci will differentially impact on breast cancer risk in different ethnic groups, if they display different frequencies or different linkage disequilibrium patterns across populations, such as CASP8*D302H that is virtually absent in Asians [121], or the ESR1 locus at which different risk alleles SNPs have emerged in Asians and Europeans [100,103,125-127]. Gene-based strategies for an improved risk prediction will therefore need to be elaborated in a population-specific way.

In addition to risk prediction, identifying the genetic basis of breast cancer in the individual patient might have further prognostic and therapeutic implications. Breast cancer therapy has been guided for long by the presence or absence of gene products such as hormone receptors or HER2/neu. These tumour characteristics are partly determined by germ-line mutations, as exemplified by BRCA1 mutations which are frequently associated with triple-negative breast cancers, but breast cancer pathology also seems to be influenced by lowpenetrance variants like those in FGFR2 that are strongly correlated with estrogen-receptor positive disease [95,96,151]. In fact, many of the hitherto identified variants appear to preferentially associate with a defined estrogen receptor status (Table 2) $[119,123,152]$. Further studies are presently underway to investigate whether SNP profiling could be of prognostic value [153].

The identification of breast cancer susceptibility alleles may also guide the development of new drugs that target additional breast cancer pathways, such as oncogenic 
signalling mediated by FGF receptors [154] or mutation accumulation mediated through ABOBEC3B. Such new drugs are particularly needed in the treatment of otherwise poorly targetable breast carcinomas such as triple-negative tumours [155] and the identification of risk alleles in genes like BABAM1 or MDM4 in this particular subgroup may offer promising avenues for new therapeutic regimens. The concept of "synthetic lethality" as exemplified by the introduction of PARP1 inhibitors into treatment of patients with $B R C A 1$ or BRCA2 mutations may also prove useful in the development of other compounds to target additional genetic predispositions [156-158].

\section{Conclusions and outlook}

Tremendous progress has been made during the past few years in deciphering the polygenic susceptibility to breast cancer. The results suggest that key pathways are targeted by different sources of genetic variation influencing the hereditary risk. To a large extent these findings fulfil the predictions made some forty years ago that "genes may either cause susceptibility of the mammary gland to hormonal action [or to a virus], or induce an easy transformation from a normal to a malignant cell" [1]. It can be anticipated that hundreds of additional loci are still to be detected that collectively form the basic layout for an individual's susceptibility to breast cancer. With many more genes being identified, a deeper understanding of breast cancer development and progression together with the ability of gene-based stratification should ultimately lead to improved prevention and an individually tailored therapy to the benefit of each patient.

\section{Abbreviations \\ CNV: Copy number variation; GWAS: Genome-wide association study; SNP: Single nucleotide polymorphism; TNBC: Triple-negative breast cancer.}

\section{Competing interests}

The authors declare that they have no competing interests.

\section{Authors' contributions}

NB worked on Table 1 and Figure 1. SH worked on Table 2 and Figure 2. TD drafted the manuscript. All authors read and approved the final manuscript.

\section{Helpful websites}

NCBI PubMed http://www.ncbi.nlm.nih.gov/pubmed

NCBI Genbank http://www.ncbi.nlm.nih.gov/gene

NCBI SNP database http://www.ncbi.nlm.nih.gov/snp

NIH GWAS Catalogue http://www.genome.gov/gwastudies/

iCOGS information http://www.nature.com/icogs/, http://www.nature.com/ ng/journal/v45/n4/full/ng.2592.html

\section{Search strategy and selection criteria}

References for this Review were identified through searches of PubMed with the search terms "breast cancer", "mutation", and "genetic susceptibility" from 1990 until March, 2013. Articles were also identified through searches of the authors' own files. Only papers published in English were reviewed. The final reference list was generated on the basis of originality and relevance to the broad scope of this Review. We apologize to all authors whose work may have been undeliberately overlooked using this approach.

\section{Author details}

${ }^{1}$ Clinics of Obstetrics and Gynaecology, Hannover Medical School, Hannover, Germany. ${ }^{2}$ Clinics of Radiation Oncology, Hannover Medical School,

Hannover, Germany.

Received: 15 April 2013 Accepted: 2 September 2013

Published: 11 September 2013

\section{References}

1. Vakil NV, Morgan RW: Etiology of breast cancer. I. Genetic aspects. CMA Journal 1973, 109:29-32.

2. Broca P: Traité des tumeurs I. Tome premier de tumeur en générale. Paris: Faculté de Médicine; 1866:150-153.

3. Warthin AS: Heredity with reference to carcinoma as shown by the study of the cases examined in the pathological laboratory of the University of Michigan, 1895-1913. Arch Intern Med 1913, 12:546-555.

4. Malkin D: Li-Fraumeni syndrome. Genes Cancer 2011, 2:475-484.

5. Malkin D, Li FP, Strong LC, Fraumeni JF Jr, Nelson CE, Kim DH, Kassel J, Gryka MA, Bischoff FZ, Tainsky MA, Friend SH: Germ line p53 mutations in a familial syndrome of breast cancer, sarcomas, and other neoplasms. Science 1990, 250:1233-1238.

6. Srivastava S, Zou ZQ, Pirollo K, Blattner W, Chang EH: Germ-line transmission of a mutated p53 gene in a cancer-prone family with Li-Fraumeni syndrome. Nature 1990, 348:747-749.

7. Miki Y, Swensen J, Shattuck-Eidens D, Futreal PA, Harshman K, Tavtigian S, Liu Q, Cochran C, Bennett LM, Ding W, et al: A strong candidate for the breast and ovarian cancer susceptibility gene BRCA1. Science 1994, 266:66-71.

8. Wooster R, Bignell G, Lancaster J, Swift S, Seal S, Mangion J, Collins N, Gregory S, Gumbs C, Micklem G: Identification of the breast cancer susceptibility gene BRCA2. Nature 1995, 378:789-792.

9. Tan MH, Mester JL, Ngeow J, Rybicki LA, Orloff MS, Eng C: Lifetime cancer risks in individuals with germline PTEN mutations. Clin Cancer Res 2012, 18:400-407.

10. Bubien V, Bonnet F, Brouste V, Hoppe S, Barouk-Simonet E, David A, Edery P, Bottani A, Layet V, Caron O, Gilbert-Dussardier B, Delnatte C, Dugast C, Fricker JP, Bonneau D, Sevenet N, Longy M, Caux F, French Cowden Disease Network: High cumulative risks of cancer in patients with PTEN hamartoma tumour syndrome. J Med Genet 2013, 50:255-263.

11. Lim W, Hearle N, Shah B, Murday V, Hodgson SV, Lucassen A, Eccles D, Talbot I, Neale K, Lim AG, O'Donohue J, Donaldson A, Macdonald RC, Young ID, Robinson MH, Lee PW, Stoodley BJ, Tomlinson I, Alderson D, Holbrook AG, Vyas S, Swarbrick ET, Lewis AA, Phillips RK, Houlston RS: Further observations on LKB1/STK11 status and cancer risk in Peutz-Jeghers syndrome. Br J Cancer 2003, 89:308-313.

12. van Lier MG, Wagner A, Mathus-Vliegen EM, Kuipers EJ, Steyerberg EW, van Leerdam ME: High cancer risk in Peutz-Jeghers syndrome: a systematic review and surveillance recommendations. Am J Gastroenterol 2010, 105:1258-1264.

13. Win AK, Lindor NM, Jenkins MA: Risk of breast cancer in Lynch syndrome: a systematic review. Breast Cancer Res 2013, 15:R27.

14. German J: Bloom's syndrome. XX. The first 100 cancers. Cancer Genet Cytogenet 1997, 93:100-106.

15. Reiman A, Srinivasan V, Barone G, Last Jl, Wootton LL, Davies EG, Verhagen MM, Willemsen MA, Weemaes CM, Byrd PJ, Izatt L, Easton DF, Thompson DJ, Taylor AM: Lymphoid tumours and breast cancer in ataxia telangiectasia, substantial protective effect of residual ATM kinase activity against childhood tumours. Br J Cancer 2011, 105:586-591.

16. Masciari S, Larsson N, Senz J, Boyd N, Kaurah P, Kandel MJ, Harris LN, Pinheiro HC, Troussard A, Miron P, Tung N, Oliveira C, Collins L, Schnitt S, Garber JE, Huntsman D: Germline E-cadherin mutations in familial lobular breast cancer. J Med Genet 2007, 44:726-731.

17. Xie ZM, Li LS, Laquet C, Penault-Llorca F, Uhrhammer N, Xie XM, Bignon YJ: Germline mutations of the E-cadherin gene in families with inherited invasive lobular breast carcinoma but no diffuse gastric cancer. Cancer 2011, 117:3112-3117.

18. Turnbull C, Rahman N: Genetic predisposition to breast cancer: past, present, and future. Annu Rev Genomics Hum Genet 2008, 9:321-345.

19. Ghoussaini M, Pharoah PD: Polygenic susceptibility to breast cancer: current state-of-the-art. Future Oncol 2009, 5:689-701. 
20. Mavaddat N, Antoniou AC, Easton DF, Garcia-Closas M: Genetic susceptibility to breast cancer. Mol Oncol 2010, 4:174-191.

21. Shuen AY, Foulkes WD: Inherited mutations in breast cancer genes-risk and response. J Mammary Gland Biol Neoplasia 2011, 16:3-15.

22. Foulkes WD: Inherited susceptibility to common cancers. N Engl J Med 2008, 359:2143-2153.

23. Domchek SM, Tang J, Stopfer J, Lilli DR, Hamel N, Tischkowitz M, Monteiro AN, Messick TE, Powers J, Yonker A, Couch FJ, Goldgar DE, Davidson HR, Nathanson KL, Foulkes WD, Greenberg RA: Biallelic Deleterious BRCA1 Mutations in a Woman with Early-Onset Ovarian Cancer. Cancer Discov 2013. Epub ahead of print.

24. Howlett NG, Taniguchi T, Olson S, Cox B, Waisfisz Q, De Die-Smulders C, Persky N, Grompe M, Joenje H, Pals G, Ikeda H, Fox EA, D'Andrea AD: Biallelic inactivation of BRCA2 in Fanconi anemia. Science 2002, 297:606-609.

25. Erkko H, Dowty JG, Nikkilä J, Syrjäkoski K, Mannermaa A, Pylkäs K, Southey MC, Holli K, Kallioniemi A, Jukkola-Vuorinen A, Kataja V, Kosma VM, Xia B, Livingston DM, Winqvist R, Hopper JL: Penetrance analysis of the PALB2 c.1592delT founder mutation. Clin Cancer Res 2008, 14:4667-4671.

26. Teo ZL, Park DJ, Provenzano E, Chatfield CA, Odefrey FA, Nguyen-Dumont T, Confab K, Dowty JG, Hopper JL, Winship I, Goldgar DE, Southey MC: Prevalence of PALB2 mutations in Australasian multiple-case breast cancer families. Breast Cancer Res 2013, 15:R17. Epub ahead of print.

27. Nikkilä J, Coleman KA, Morrissey D, Pylkäs K, Erkko H, Messick TE, Karppinen SM, Amelina A, Winqvist R, Greenberg RA: Familial breast cancer screening reveals an alteration in the RAP80 UIM domain that impairs DNA damage response function. Oncogene 2009, 28:1843-1852.

28. Solyom S, Aressy B, Pylkäs K, Patterson-Fortin J, Hartikainen JM, Kallioniemi A, Kauppila S, Nikkilä J, Kosma VM, Mannermaa A, Greenberg RA, Winqvist R: Breast cancer-associated Abraxas mutation disrupts nuclear localization and DNA damage response functions. Sci Trans/ Med 2012, 4:122ra23.

29. Meindl A, Hellebrand H, Wiek C, Erven V, Wappenschmidt B, Niederacher D, Freund M, Lichtner P, Hartmann L, Schaal H, Ramser J, Honisch E, Kubisch C, Wichmann HE, Kast K, Deissler H, Engel C, Müller-Myhsok B, Neveling K, Kiechle M, Mathew CG, Schindler D, Schmutzler RK, Hanenberg H: Germline mutations in breast and ovarian cancer pedigrees establish RAD51C as a human cancer susceptibility gene. Nat Genet 2010, 42:410-414.

30. Pelttari LM, Heikkinen T, Thompson D, Kallioniemi A, Schleutker J, Holli K, Blomqvist C, Aittomäki K, Bützow R, Nevanlinna H: RAD51C is a susceptibility gene for ovarian cancer. Hum Mol Genet 2011, 20:3278-3288.

31. Loveday C, Turnbull C, Ramsay E, Hughes D, Ruark E, Frankum JR, Bowden G, Kalmyrzaev B, Warren-Perry M, Snape K, Adlard JW, Barwell J, Berg J, Brady AF, Brewer C, Brice G, Chapman C, Cook J, Davidson R, Donaldson A, Douglas F, Greenhalgh L, Henderson A, Izatt L, Kumar A, Lalloo F, Miedzybrodzka Z, Morrison PJ, Paterson J, Porteous M, Rogers MT, Shanley S, Walker L, Breast Cancer Susceptibility Collaboration (UK), Eccles D, Evans DG, Renwick A, Seal S, Lord CJ, Ashworth A, Reis-Filho JS, Antoniou AC, Rahman N: Germline mutations in RAD51D confer susceptibility to ovarian cancer. Nat Genet 2011, 43:879-882

32. Pelttari LM, Kiiski J, Nurminen $R$, Kallioniemi $A$, Schleutker J, Gylfe A, Aaltonen LA, Leminen A, Heikkilä P, Blomqvist C, Bützow R, Aittomäki K, Nevanlinna H: A Finnish founder mutation in RAD51D: analysis in breast, ovarian, prostate, and colorectal cancer. J Med Genet 2012, 49:429-432.

33. Seal $S$, Thompson D, Renwick A, Elliott A, Kelly P, Barfoot R, Chagtai T, Jayatilake H, Ahmed M, Spanova K, North B, McGuffog L, Evans DG, Eccles D, Breast Cancer Susceptibility Collaboration (UK), Easton DF, Stratton MR, Rahman N: Truncating mutations in the Fanconi anemia J gene BRIP1 are low-penetrance breast cancer susceptibility alleles. Nat Genet 2006, 38:1239-1241

34. Rafnar T, Gudbjartsson DF, Sulem $P$, Jonasdottir A, Sigurdsson A, Jonasdottir A, Besenbacher S, Lundin P, Stacey SN, Gudmundsson J, Magnusson OT, le Roux L, Orlygsdottir G, Helgadottir HT, Johannsdottir H, Gylfason A, Tryggvadottir L, Jonasson JG, de Juan A, Ortega E, Ramon-Cajal JM, GarcíaPrats MD, Mayordomo C, Panadero A, Rivera F, Aben KK, van Altena AM, Massuger LF, Aavikko M, Kujala PM, Staff S, Aaltonen LA, Olafsdottir K, Bjornsson J, Kong A, Salvarsdottir A, Saemundsson H, Olafsson K, Benediktsdottir KR, Gulcher J, Masson G, Kiemeney LA, Mayordomo Jl, Thorsteinsdottir U, Stefansson K: Mutations in BRIP1 confer high risk of ovarian cancer. Nat Genet 2011, 43:1104-1107.

35. Swift M, Reitnauer PJ, Morrell D, Chase CL: Breast and other cancers in families with ataxia-telangiectasia. N Engl J Med 1987, 316:1289-1294.
36. Shiloh Y, Ziv Y: The ATM protein kinase: regulating the cellular response to genotoxic stress, and more. Nat Rev Mol Cell Biol 2013, 14:197-210.

37. Renwick A, Thompson D, Seal S, Kelly P, Chagtai T, Ahmed M, North B, Jayatilake H, Barfoot R, Spanova K, McGuffog L, Evans DG, Eccles D, Breast Cancer Susceptibility Collaboration (UK), Easton DF, Stratton MR, Rahman N: ATM mutations that cause ataxia-telangiectasia are breast cancer susceptibility alleles. Nat Genet 2006, 38:873-875.

38. Pylkäs K, Tommiska J, Syrjäkoski K, Kere J, Gatei M, Waddell N, Allinen M, Karppinen SM, Rapakko K, Kääriäinen H, Aittomäki K, Blomqvist C, Mustonen A Holli K, Khanna KK, Kallioniemi OP, Nevanlinna H, Winqvist R: Evaluation of the role of Finnish ataxia-telangiectasia mutations in hereditary predisposition to breast cancer. Carcinogenesis 2007, 28:1040-1045.

39. Bogdanova N, Cybulski C, Bermisheva M, Datsyuk I, Yamini P, Hillemanns P, Antonenkova NN, Khusnutdinova E, Lubinski J, Dörk T: A nonsense mutation (E1978X) in the ATM gene is associated with breast cancer. Breast Cancer Res Treat 2009, 118:207-211.

40. Bartkova J, Tommiska J, Oplustilova L, Aaltonen K, Tamminen A, Heikkinen T, Mistrik M, Aittomäki K, Blomqvist C, Heikkilä P, Lukas J, Nevanlinna H, Bartek $\mathrm{J}$ : Aberrations of the MRE11-RAD50-NBS1 DNA damage sensor complex in human breast cancer: MRE11 as a candidate familial cancer-predisposing gene. Mol Oncol 2008, 2:296-316.

41. Górski B, Cybulski C, Huzarski T, Byrski T, Gronwald J, Jakubowska A, Stawicka M, Gozdecka-Grodecka S, Szwiec M, Urbański K, Mituś J, Marczyk E, Dziuba J, Wandzel P, Surdyka D, Haus O, Janiszewska H, Debniak T, Tołoczko-Grabarek A, Medrek K, Masojć B, Mierzejewski M, Kowalska E, Narod SA, Lubiński J: Breast cancer predisposing alleles in Poland. Breast Cancer Res Treat 2005, 92:19-24.

42. Steffen J, Nowakowska D, Niwinska A, Czapczak D, Kluska A, Piatkowska M, Wisniewska A, Paszko Z: Germline mutations 657 del5 of the NBS1 gene contribute significantly to the incidence of breast cancer in Central Poland. Int J Cancer 2006, 119:472-475.

43. Bogdanova N, Feshchenko S, Schürmann P, Waltes R, Wieland B, Hillemanns P, Rogov Yl, Dammann O, Bremer M, Karstens JH, Sohn C, Varon R, Dörk T: Nijmegen Breakage Syndrome mutations and risk of breast cancer. Int J Cancer 2008, 122:802-806.

44. Heikkinen K, Rapakko K, Karppinen SM, Erkko H, Knuutila S, Lundán T, Mannermaa A, Børresen-Dale AL, Borg A, Barkardottir RB, Petrini J, Winqvist R: RAD50 and NBS1 are breast cancer susceptibility genes associated with genomic instability. Carcinogenesis 2006, 27:1593-1599.

45. Sokolenko AP, lyevleva AG, Preobrazhenskaya EV, Mitiushkina NV, Abysheva SN, Suspitsin EN, Kuligina ES, Gorodnova TV, Pfeifer W, Togo AV, Turkevich EA, Ivantsov AO, Voskresenskiy DV, Dolmatov GD, Bit-Sava EM, Matsko DE, Semiglazov VF, Fichtner I, Larionov AA, Kuznetsov SG, Antoniou AC, Imyanitov EN: High prevalence and breast cancer predisposing role of the BLM c.1642 C > T (Q548X) mutation in Russia. Int J Cancer 2012, 130:2867-2873.

46. Prokofyeva D, Bogdanova N, Dubrowinskaja N, Bermisheva M, Takhirova Z, Antonenkova N, Turmanov N, Datsyuk I, Gantsev S, Christiansen H, Park-Simon TW, Hillemanns P, Khusnutdinova E, Dörk T: Nonsense mutation p.Q548X in BLM, the gene mutated in Bloom's syndrome, is associated with breast cancer in Slavic populations. Breast Cancer Res Treat 2013, 137:533-539.

47. Thompson ER, Doyle MA, Ryland GL, Rowley SM, Choong DY, Tothill RW Thorne H, kConFab, Barnes DR, Li J, Ellul J, Philip GK, Antill YC, James PA, Trainer AH, Mitchell G, Campbell IG: Exome sequencing identifies rare deleterious mutations in DNA repair genes FANCC and BLM as potential breast cancer susceptibility alleles. PLOS Genet 2012, 8:e1002894.

48. Berwick M, Satagopan JM, Ben-Porat L, Carlson A, Mah K, Henry R, Diotti R, Milton K, Pujara K, Landers T, Dev Batish S, Morales J, Schindler D, Hanenberg H, Hromas R, Levran O, Auerbach AD: Genetic heterogeneity among Fanconi anemia heterozygotes and risk of cancer. Cancer Res 2007, 67:9591-9596.

49. Gracia-Aznarez FJ, Fernandez V, Pita G, Peterlongo P, Dominguez O, de la Hoya M, Duran M, Osorio A, Moreno L, Gonzalez-Neira A, Rosa-Rosa JM, Sinilnikova O, Mazoyer S, Hopper J, Lazaro C, Southey M, Odefrey F, Manoukian S, Catucci I, Caldes T, Lynch HT, Hilbers FS, van Asperen CJ, Vasen HF, Goldgar D, Radice P, Devilee P, Benitez J: Whole exome sequencing suggests much of non-BRCA1/BRCA2 familial breast cancer is due to moderate and low penetrance susceptibility alleles. PLoS One 2013, 8:e55681.

50. Bakker JL, van Mil SE, Crossan G, Sabbaghian N, De Leeneer K, Poppe B, Adank M, Gille H, Verheul $H$, Meijers-Heijboer $H$, de Winter JP, Claes K, 
Tischkowitz M, Waisfisz Q: Analysis of the novel fanconi anemia gene SLX4/FANCP in familial breast cancer cases. Hum Mutat 2013, 34:70-73.

51. Shah S, Kim Y, Ostrovnaya I, Murali R, Schrader KA, Lach FP, Sarrel K, Rau-Murthy R, Hansen N, Zhang L, Kirchhoff T, Stadler Z, Robson M, Vijai J, Offit K, Smogorzewska A: Assessment of SLX4 Mutations in Hereditary Breast Cancers. PLoS One 2013, 8:e66961.

52. Hilbers FS, Wijnen JT, Hoogerbrugge N, Oosterwijk JC, Collee MJ, Peterlongo P, Radice P, Manoukian S, Feroce I, Capra F, Couch FJ, Wang X, Guidugli L, Offit K, Shah S, Campbell IG, Thompson ER, James PA, Trainer AH, Gracia J, Benitez J, van Asperen CJ, Devilee P: Rare variants in XRCC2 as breast cancer susceptibility alleles. J Med Genet 2012, 49:618-620.

53. Meijers-Heijboer $\mathrm{H}$, van den Ouweland A, Klijn J, Wasielewski M, de Snoo A, Oldenburg R, Hollestelle A, Houben M, Crepin E, van Veghel-Plandsoen M, Elstrodt F, van Duijn C, Bartels C, Meijers C, Schutte M, McGuffog L, Thompson D, Easton D, Sodha N, Seal S, Barfoot R, Mangion J, Chang-Claude J, Eccles D, Eeles R, Evans DG, Houlston R, Murday V, Narod S, Peretz T, Peto J, Phelan C, Zhang HX, Szabo C, Devilee P, Goldgar D, Futreal PA, Nathanson KL, Weber B, Rahman N, Stratton MR: CHEK2-Breast Cancer Consortium, Low-penetrance susceptibility to breast cancer due to CHEK2 $\left.{ }^{*}\right) 1100$ delC in noncarriers of BRCA1 or BRCA2 mutations. Nat Genet 2002, 31:55-59.

54. Vahteristo P, Bartkova J, Eerola H, Syrjäkoski K, Ojala S, Kilpivaara O, Tamminen A, Kononen J, Aittomäki K, Heikkilä P, Holli K, Blomqvist C, Bartek J, Kallioniemi OP, Nevanlinna H: A CHEK2 genetic variant contributing to a substantial fraction of familial breast cancer. Am J Hum Genet 2002, 71:432-438.

55. CHEK2 Breast Cancer Case-control Consortium: CHEK2*1100delC and susceptibility to breast cancer: a collaborative analysis involving 10,860 breast cancer cases and 9,065 controls from 10 studies. Am J Hum Genet 2004, 74:1175-1182.

56. Adank MA, Jonker MA, Kluijt I, van Mil SE, Oldenburg RA, Mooi WJ, Hogervorst FB, van den Ouweland AM, Gille JJ, Schmidt MK, van der Vaart AW, Meijers-Heijboer H, Waisfisz Q: CHEK2*1100delC homozygosity is associated with a high breast cancer risk in women. J Med Genet 2011, 48:860-863.

57. Cybulski C, Wokołorczyk D, Huzarski T, Byrski T, Gronwald J, Górski B, Debniak T, Masojé B, Jakubowska A, van de Wetering T, Narod SA, Lubiński $\mathrm{J}$ : A deletion in CHEK2 of 5,395 bp predisposes to breast cancer in Poland. Breast Cancer Res Treat 2007, 102:119-122.

58. Bogdanova N, Enssen-Dubrowinskaja N, Feshchenko S, Lazjuk GI, Rogov YI, Dammann O, Bremer M, Karstens JH, Sohn C, Dörk T: Association of two mutations in the CHEK2 gene with breast cancer. Int J Cancer 2005, 116:263-266.

59. Ruark E, Snape K, Humburg P, Loveday C, Bajrami I, Brough R, Rodrigues DN, Renwick A, Seal S, Ramsay E, Duarte Sdel V, Rivas MA, Warren-Perry M, Zachariou A, Campion-Flora A, Hanks S, Murray A, Ansari Pour N, Douglas J, Gregory L, Rimmer A, Walker NM, Yang TP, Adlard JW, Barwell J, Berg J, Brady AF, Brewer C, Brice G, Chapman C, Cook J, Davidson R, Donaldson A, Douglas F, Eccles D, Evans DG, Greenhalgh L, Henderson A, lzatt L, et al: Mosaic PPM1D mutations are associated with predisposition to breast and ovarian cancer. Nature 2013, 493:406-410.

60. Antoniou A, Pharoah PD, Narod S, Risch HA, Eyfjord JE, Hopper JL, Loman N, Olsson H, Johannsson O, Borg A, Pasini B, Radice P, Manoukian S, Eccles DM, Tang N, Olah E, Anton-Culver H, Warner E, Lubinski J, Gronwald J, Gorski B, Tulinius H, Thorlacius S, Eerola H, Nevanlinna H, Syrjäkoski K, Kallioniemi OP, Thompson D, Evans C, Peto J, Lalloo F, Evans DG, Easton DF: Average risks of breast and ovarian cancer associated with BRCA1 or BRCA2 mutations detected in case series unselected for family history: a combined analysis of 22 studies. Am J Hum Genet 2003, 72:1117-1130.

61. King MC, Marks JH, Mandell JB, New York Breast Cancer Study Group: Breast and ovarian cancer risks due to inherited mutations in BRCA1 and BRCA2. Science 2003, 302:643-646.

62. Fackenthal JD, Olopade Ol: Breast cancer risk associated with BRCA1 and BRCA2 in diverse populations. Nat Rev Cancer 2007, 7:937-948

63. Antoniou AC, Sinilnikova OM, Simard J, Léoné M, Dumont M, Neuhausen SL, Struewing JP, Stoppa-Lyonnet D, Barjhoux L, Hughes DJ, Coupier I, Belotti M, Lasset C, Bonadona V, Bignon YJ, Genetic Modifiers of Cancer Risk in BRCA1/2 Mutation Carriers Study (GEMO), Rebbeck TR, Wagner T, Lynch HT, Domchek SM, Nathanson KL, Garber JE, Weitzel J, Narod SA, Tomlinson G, Olopade Ol, Godwin A, Isaacs C, Jakubowska A, Lubinski J, Gronwald J, Górski B, Consortium of Investigators of Modifiers of BRCA1/2 (CIMBA), et al:
RAD51 135G->C modifies breast cancer risk among BRCA2 mutation carriers: results from a combined analysis of 19 studies. Am J Hum Genet 2007, 81:1186-1200.

64. Ramus SJ, Kartsonaki C, Gayther SA, Pharoah PD, Sinilnikova OM, Beesley J, Chen X, McGuffog L, Healey S, Couch FJ, Wang X, Fredericksen Z, Peterlongo P, Manoukian S, Peissel B, Zaffaroni D, Roversi G, Barile M, Viel A, Allavena A, Ottini L, Papi L, Gismondi V, Capra F, Radice P, Greene MH, Mai PL, Andrulis IL, Glendon G, Ozcelik H, OCGN, Thomassen M, Gerdes AM, Kruse TA, Cruger D, Jensen UB, Caligo MA, Olsson H, Kristoffersson U, Lindblom A, Arver B, Karlsson P, Stenmark Askmalm M, Borg A, Consortium of Investigators of Modifiers of BRCA1/2, et al: Genetic variation at 9p22.2 and ovarian cancer risk for BRCA1 and BRCA2 mutation carriers. J Natl Cancer Inst 2011, 103:105-116.

65. Rebbeck TR, Mitra N, Domchek SM, Wan F, Friebel TM, Tran TV, Singer CF, Tea MK, Blum JL, Tung N, Olopade Ol, Weitzel JN, Lynch HT, Snyder CL, Garber JE, Antoniou AC, Peock S, Evans DG, Paterson J, Kennedy MJ, Donaldson A, Dorkins H, Easton DF, Epidemiological Study of BRCA1 and BRCA2 Mutation Carriers (EMBRACE), Rubinstein WS, Daly MB, Isaacs C, Nevanlinna H, Couch FJ, Andrulis IL, Freidman E, Laitman Y, Ganz PA, Tomlinson GE, Neuhausen SL, Narod SA, Phelan CM, Greenberg R, Nathanson KL: Modification of BRCA1-Associated Breast and Ovarian Cancer Risk by BRCA1-Interacting Genes. Cancer Res 2011, 71:5792-5805.

66. Roy R, Chun J, Powell SN: BRCA1 and BRCA2: different roles in a common pathway of genome protection. Nat Rev Cancer 2011, 12:68-78.

67. Tischkowitz MD, Foulkes WD: The basal phenotype of BRCA1-related breast cancer: past, present and future. Cell Cycle 2006, 5:963-7.

68. Thompson D, Easton D, Breast Cancer Linkage Consortium: Variation in cancer risks, by mutation position, in BRCA2 mutation carriers. Am J Hum Genet 2001, 68:410-419.

69. Thompson D, Easton D, Breast Cancer Linkage Consortium: Variation in BRCA1 cancer risks by mutation position. Cancer Epidemiol Biomarkers Prev 2002, 11:329-336

70. Bogdanova NV, Antonenkova NN, Rogov YI, Karstens JH, Hillemanns P, Dörk T: High frequency and allele-specific differences of BRCA1 founder mutations in breast cancer and ovarian cancer patients from Belarus. Clin Genet 2010, 78:364-372.

71. Spurdle AB, Whiley PJ, Thompson B, Feng B, Healey S, Brown MA, Pettigrew C, KConFab, Van Asperen CJ, Ausems MG, Kattentidt-Mouravieva AA, van den Ouweland AM, Dutch Belgium UV Consortium, Lindblom A, Pigg MH, Schmutzler RK, Engel C, Meindl A, German Consortium of Hereditary Breast and Ovarian Cancer, Caputo S, Sinilnikova OM, Lidereau R, French COVAR group collaborators, Couch FJ, Guidugli L, Hansen T, Thomassen M, Eccles DM, Tucker K, Benitez J, Domchek SM, Toland AE, Van Rensburg EJ, Wappenschmidt B, Borg A, Vreeswijk MP, Goldgar DE, ENIGMA Consortium: BRCA1 R1699Q variant displaying ambiguous functional abrogation confers intermediate breast and ovarian cancer risk. J Med Genet 2012, 49:525-532.

72. Michailidou K, Hall P, Gonzalez-Neira A, Ghoussaini M, Dennis J, Milne RL, Schmidt MK, Chang-Claude J, Bojesen SE, Bolla MK, Wang Q, Dicks E, Lee A, Turnbull C, Rahman N, Breast and Ovarian Cancer Susceptibility Collaboration, Fletcher O, Peto J, Gibson L, Dos Santos Silva I, Nevanlinna H, Muranen TA, Aittomäki K, Blomqvist C, Czene K, Irwanto A, Liu J, Waisfisz Q, Meijers-Heijboer H, Adank M, Hereditary Breast and Ovarian Cancer Research Group Netherlands (HEBON), et al: Large-scale genotyping identifies 41 new loci associated with breast cancer risk. Nat Genet 2013, 45:353-361.

73. Rahman N, Seal S, Thompson D, Kelly P, Renwick A, Elliott A, Reid S, Spanova K, Barfoot R, Chagtai T, Jayatilake H, McGuffog L, Hanks S, Evans DG, Eccles D, Breast Cancer Susceptibility Collaboration (UK), Easton DF, Stratton MR: PALB2, which encodes a BRCA2-interacting protein, is a breast cancer susceptibility gene. Nat Genet 2007, 39:165-167.

74. Erkko H, Xia B, Nikkilä J, Schleutker J, Syriäkoski K, Mannermaa A, Kallioniemi A, Pylkäs K, Karppinen SM, Rapakko K, Miron A, Sheng Q, Li G, Mattila H, Bell DW, Haber DA, Grip M, Reiman M, Jukkola-Vuorinen A, Mustonen A, Kere J, Aaltonen LA, Kosma VM, Kataja V, Soini Y, Drapkin RI, Livingston DM, Winqvist R: A recurrent mutation in PALB2 in Finnish cancer families. Nature 2007, 446:316-319.

75. Dansonka-Mieszkowska A, Kluska A, Moes J, Dabrowska M, Nowakowska D, Niwinska A, Derlatka P, Cendrowski K, Kupryjanczyk J: A novel germline PALB2 deletion in Polish breast and ovarian cancer patients. BMC Med Genet 2010, 11:20. 
76. Prokofyeva D, Bogdanova N, Bermisheva M, Zinnatullina G, Hillemanns P, Khusnutdinova E, Dörk T: Rare occurrence of PALB2 mutations in ovarian cancer patients from the Volga-Ural region. Clin Genet 2012, 82:100-101.

77. Huen MS, Sy SM, Chen J: BRCA1 and its toolbox for the maintenance of genome integrity. Nat Rev Mol Cell Biol 2010, 11:138-148.

78. Le Calvez-Kelm F, Oliver J, Damiola F, Forey N, Robinot N, Durand G, Voegele C, Vallée MP, Byrnes G, Registry BC, Hopper JL, Southey MC, Andrulis IL, John EM, Tavtigian SV, Lesueur F: RAD51 and breast cancer susceptibility: no evidence for rare variant association in the Breast Cancer Family Registry study. PLoS One 2012, 7:e52374.

79. Bell DW, Wahrer DC, Kang DH, MacMahon MS, FitzGerald MG, Ishioka C, Isselbacher KJ, Krainer M, Haber DA: Common nonsense mutations in RAD52. Cancer Res 1999, 59:3883-3888.

80. Han J, Hankinson SE, De Vivo I, Colditz GA, Hunter DJ: No association between a stop codon polymorphism in RAD52 and breast cancer risk. Cancer Epidemiol Biomarkers Prev 2002, 11:1138-1139.

81. Matsuda M, Miyagawa K, Takahashi M, Fukuda T, Kataoka T, Asahara T, Inui H, Watatani M, Yasutomi M, Kamada N, Dohi K, Kamiya K: Mutations in the RAD54 recombination gene in primary cancers. Oncogene 1999, 18:3427-3430.

82. Park DJ, Lesueur F, Nguyen-Dumont T, Pertesi M, Odefrey F, Hammet F, Neuhausen SL, John EM, Andrulis IL, Terry MB, Daly M, Buys S, Le Calvez-Kelm F, Lonie A, Pope BJ, Tsimiklis H, Voegele C, Hilbers FM, Hoogerbrugge N, Barroso A, Osorio A, Breast Cancer Family Registry, Kathleen Cuningham Foundation Consortium for Research into Familial Breast Cancer, Giles GG, Devilee P, Benitez J, Hopper JL, Tavtigian SV, Goldgar DE, Southey MC: Rare mutations in XRCC2 increase the risk of breast cancer. Am J Hum Genet 2012, 90:734-739.

83. Seal S, Barfoot R, Jayatilake H, Smith P, Renwick A, Bascombe L, McGuffog L, Evans DG, Eccles D, Easton DF, Stratton MR, Rahman N, Breast Cancer Susceptibility Collaboration: Evaluation of Fanconi Anemia genes in familial breast cancer predisposition. Cancer Res 2003, 63:8596-8599.

84. de Garibay GR, Díaz A, Gaviña B, Romero A, Garre P, Vega A, Blanco A, Tosar A, Díez O, Pérez-Segura P, Díaz-Rubio E, Caldés T, de la Hoya M: Low prevalence of SLX4 loss-of-function mutations in non-BRCA1/2 breast and/or ovarian cancer families. Eur J Hum Genet 2013, 21:883-886.

85. Williams GJ, Lees-Miller SP, Tainer JA: Mre11-Rad50-Nbs1 conformations and the control of sensing, signaling, and effector responses at DNA double-strand breaks. DNA Repair 2010, 9:1299-1306.

86. Varon R, Vissinga C, Platzer M, Cerosaletti KM, Chrzanowska KH, Saar K, Beckmann G, Seemanová E, Cooper PR, Nowak NJ, Stumm M, Weemaes CM Gatti RA, Wilson RK, Digweed M, Rosenthal A, Sperling K, Concannon P, Reis A: Nibrin, a novel DNA double-strand break repair protein, is mutated in Nijmegen breakage syndrome. Cell 1998, 93:467-476.

87. Waltes R, Kalb R, Gatei M, Kijas AW, Stumm M, Sobeck A, Wieland B, Varon R, Lerenthal $Y$, Lavin MF, Schindler D, Dörk T: Human RAD50 deficiency in a Nijmegen breakage syndrome-like disorder. Am J Hum Genet 2009, 84:605-616.

88. Stewart GS, Maser RS, Stankovic T, Bressan DA, Kaplan MI, Jaspers NG, Raams A, Byrd PJ, Petrini JH, Taylor AM: The DNA double-strand break repair gene hMRE11 is mutated in individuals with an ataxia-telangiectasia-like disorder. Cell 1999, 99:577-587.

89. Walsh T, Casadei S, Lee MK, Pennil CC, Nord AS, Thornton AM, Roeb W, Agnew KJ, Stray SM, Wickramanayake A, Norquist B, Pennington KP, Garcia RL, King MC, Swisher EM: Mutations in 12 genes for inherited ovarian, fallopian tube, and peritoneal carcinoma identified by massively parallel sequencing. Proc Natl Acad Sci U S A 2011, 108:18032-18037.

90. Ellis NA, Groden J, Ye TZ, Straughen J, Lennon DJ, Ciocci S, Proytcheva M, German J: The Bloom's syndrome gene product is homologous to RecQ helicases. Cell 1995, 83:655-666.

91. German J, Sanz MM, Ciocci S, Ye TZ, Ellis NA: Syndrome-causing mutations of the BLM gene in persons in the Bloom's Syndrome Registry. Hum Mutat 2007, 28:743-753.

92. Nevanlinna H, Bartek J: The CHEK2 gene and inherited breast cancer susceptibility. Oncogene 2006, 25:5912-5919.

93. Cybulski C, Górski B, Huzarski T, Masojć B, Mierzejewski M, Debniak T, Teodorczyk U, Byrski T, Gronwald J, Matyjasik J, Zlowocka E, Lenner M, Grabowska E, Nej K, Castaneda J, Medrek K, Szymańska A, Szymańska J, Kurzawski G, Suchy J, Oszurek O, Witek A, Narod SA, Lubiński J: CHEK2 is a multiorgan cancer susceptibility gene. Am J Hum Genet 2004, 75:1131-1135.

94. Pharoah PD, Antoniou A, Bobrow M, Zimmern RL, Easton DF, Ponder BA: Polygenic susceptibility to breast cancer and implications for prevention. Nat Genet 2002, 31:33-36.
95. Easton DF, Pooley KA, Dunning AM, Pharoah PD, Thompson D, Ballinger DG, Struewing JP, Morrison J, Field H, Luben R, Wareham N, Ahmed S, Healey CS, Bowman R, SEARCH collaborators, Meyer KB, Haiman CA, Kolonel LK, Henderson BE, Le Marchand L, Brennan P, Sangrajrang S, Gaborieau V, Odefrey F, Shen CY, Wu PE, Wang HC, Eccles D, Evans DG, Peto J, Fletcher O, Johnson N, Seal S, Stratton MR, Rahman N, Chenevix-Trench G, Bojesen SE, et al: Genome-wide association study identifies novel breast cancer susceptibility loci. Nature 2007, 447:1087-1093.

96. Hunter DJ, Kraft P, Jacobs KB, Cox DG, Yeager M, Hankinson SE, Wacholder S, Wang Z, Welch R, Hutchinson A, Wang J, Yu K, Chatterjee N, Orr N, Willett WC, Colditz GA, Ziegler RG, Berg CD, Buys SS, McCarty CA, Feigelson HS, Calle EE, Thun MJ, Hayes RB, Tucker M, Gerhard DS, Fraumeni JF Jr, Hoover $\mathrm{RN}$, Thomas G, Chanock SJ: A genome-wide association study identifies alleles in FGFR2 associated with risk of sporadic postmenopausal breast cancer. Nat Genet 2007, 39:870-874.

97. Stacey SN, Manolescu A, Sulem P, Rafnar T, Gudmundsson J, Gudjonsson SA, Masson G, Jakobsdottir M, Thorlacius S, Helgason A, Aben KK, Strobbe LJ, Albers-Akkers MT, Swinkels DW, Henderson BE, Kolonel LN, Le Marchand L, Millastre E, Andres R, Godino J, Garcia-Prats MD, Polo E, Tres A, Mouy M, Saemundsdottir J, Backman VM, Gudmundsson L, Kristjansson K, Bergthorsson JT, Kostic J, Frigge ML, Geller F, Gudbjartsson D, et al: Common variants on chromosomes $2 \mathrm{q} 35$ and $16 \mathrm{q} 12$ confer susceptibility to estrogen receptor-positive breast cancer. Nat Genet 2007, 39:865-869.

98. Ahmed S, Thomas G, Ghoussaini M, Healey CS, Humphreys MK, Platte R, Morrison J, Maranian M, Pooley KA, Luben R, Eccles D, Evans DG, Fletcher O, Johnson N, dos Santos Silva I, Peto J, Stratton MR, Rahman N, Jacobs K, Prentice R, Anderson GL, Rajkovic A, Curb JD, Ziegler RG, Berg CD, Buys SS, McCarty CA, Feigelson HS, Calle EE, Thun MJ, Diver WR, Bojesen S, Nordestgaard BG, Flyger $H$, Dörk T, Schürmann P, Hillemanns $P$, Karstens JH, Bogdanova NV, Antonenkova NN, Zalutsky IV, Bermisheva M, Fedorova S, Khusnutdinova E, SEARCH, Kang D, et al: Newly discovered breast cancer susceptibility loci on 3p24 and 17q23.2. Nat Genet 2009, 41:585-590.

99. Thomas G, Jacobs KB, Kraft P, Yeager M, Wacholder S, Cox DG, Hankinson SE, Hutchinson A, Wang Z, Yu K, Chatterjee N, Garcia-Closas M, Gonzalez-Bosquet J, Prokunina-Olsson L, Orr N, Willett WC, Colditz GA, Ziegler RG, Berg CD, Buys SS, McCarty CA, Feigelson HS, Calle EE, Thun MJ, Diver R, Prentice R, Jackson R, Kooperberg C, Chlebowski R, Lissowska J, Peplonska B, Brinton LA, Sigurdson A, Doody M, Bhatti P, Alexander BH, Buring J, Lee IM, Vatten $\sqcup$, Hveem K, Kumle M, Hayes RB, Tucker M, Gerhard DS, Fraumeni JF Jr, Hoover RN, Chanock SJ, Hunter DJ: A multistage genome-wide association study in breast cancer identifies two new risk alleles at $1 \mathrm{p} 11.2$ and 14q24.1 (RAD51L1). Nat Genet 2009, 41:579-584.

100. Zheng W, Long J, Gao YT, Li C, Zheng Y, Xiang YB, Wen W, Levy S, Deming SL, Haines JL, Gu K, Fair AM, Cai Q, Lu W, Shu XO: Genome-wide association study identifies a new breast cancer susceptibility locus at 6q25.1. Nat Genet 2009, 41:324-328.

101. Turnbull C, Ahmed S, Morrison J, Pernet D, Renwick A, Maranian M, Seal S, Ghoussaini M, Hines S, Healey CS, Hughes D, Warren-Perry M, Tapper W, Eccles D, Evans DG, Breast Cancer Susceptibility Collaboration (UK), Hooning M, Schutte M, van den Ouweland A, Houlston R, Ross G, Langford C, Pharoah PD, Stratton MR, Dunning AM, Rahman N, Easton DF: Genome-wide association study identifies five new breast cancer susceptibility loci. Nat Genet 2010, 42:504-507.

102. Antoniou AC, Wang X, Fredericksen ZS, McGuffog L, Tarrell R, Sinilnikova OM, Healey S, Morrison J, Kartsonaki C, Lesnick T, Ghoussaini M, Barrowdale D, EMBRACE, Peock S, Cook M, Oliver C, Frost D, Eccles D, Evans DG, Eeles R, Izatt L, Chu C, Douglas F, Paterson J, Stoppa-Lyonnet D, Houdayer C, Mazoyer S, Giraud S, Lasset C, Remenieras A, Caron O, Hardouin A, Berthet P, GEMO Study Collaborators, Hogervorst FB, Rookus MA, Jager A, van den Ouweland A, Hoogerbrugge N, van der Luijt RB, Meijers-Heijboer H, Gómez García EB, et al: A locus on 19p13 modifies risk of breast cancer in BRCA1 mutation carriers and is associated with hormone receptor-negative breast cancer in the general population. Nat Genet 2010, 42:885-892.

103. Fletcher O, Johnson N, Orr N, Hosking FJ, Gibson LJ, Walker K, Zelenika D, Gut I, Heath S, Palles C, Coupland B, Broderick P, Schoemaker M, Jones M, Williamson J, Chilcott-Burns S, Tomczyk K, Simpson G, Jacobs KB, Chanock SJ, Hunter DJ, Tomlinson IP, Swerdlow A, Ashworth A, Ross G, os Santos Silva I, Lathrop M, Houlston RS, Peto J: Novel breast cancer susceptibility locus at 9q31.2: results of a genome-wide association study. J Natl Cancer Inst 2011, 103:425-435. 
104. Haiman CA, Chen GK, Vachon CM, Canzian F, Dunning A, Millikan RC, Wang X, Ademuyiwa F, Ahmed S, Ambrosone CB, Baglietto L, Balleine R, Bandera EV, Beckmann MW, Berg CD, Bernstein L, Blomqvist C, Blot WJ, Brauch H, Buring JE, Carey LA, Carpenter JE, Chang-Claude J, Chanock SJ, Chasman DI, Clarke CL, Cox A, Cross SS, Deming SL, Diasio RB, Dimopoulos AM, Driver WR, Dünnebier T, Durcan L, Eccles D, Edlund CK, Ekici AB, et al: A common variant at the TERT-CLPTM1L locus is associated with estrogen receptor-negative breast cancer. Nat Genet 2011, 43:1210-1214.

105. Sehrawat B, Sridharan M, Ghosh S, Robson P, Cass CE, Mackey JR, Greiner R, Damaraju S: Potential novel candidate polymorphisms identified in genome-wide association study for breast cancer susceptibility. Hum Genet 2011, 130:529-537.

106. Cai Q, Long J, Lu W, Qu S, Wen W, Kang D, Lee JY, Chen K, Shen H, Shen CY, Sung H, Matsuo K, Haiman CA, Khoo US, Ren Z, Iwasaki M, Gu K, Xiang YB, Choi JY, Park SK, Zhang L, Hu Z, Wu PE, Noh DY, Tajima K, Henderson BE, Chan KY, Su F, Kasuga Y, Wang W, Cheng JR, Yoo KY, Lee JY, Zheng H, Liu Y, Shieh YL, Kim SW, Lee JW, Iwata H, Le Marchand L, Chan SY, Xie X, Tsugane S, Lee MH, Wang S, Li G, Levy S, Huang B, Shi J, Delahanty R, Zheng Y, Li C, Gao YT, Shu XO, Zheng W: Genome-wide association study identifies breast cancer risk variant at 10q21.2: results from the Asia Breast Cancer Consortium. Hum Mol Genet 2011, 20:4991-4999.

107. Long J, Cai Q, Sung H, Shi J, Zhang B, Choi JY, Wen W, Delahanty RJ, Lu W, Gao YT, Shen H, Park SK, Chen K, Shen CY, Ren Z, Haiman CA, Matsuo K, Kim MK, Khoo US, Iwasaki M, Zheng Y, Xiang YB, Gu K, Rothman N, Wang W, Hu Z, Liu Y, Yoo KY, Noh DY, Han BG, Lee MH, Zheng H, Zhang L, Wu PE, Shieh YL, Chan SY, Wang S, Xie X, Kim SW, Henderson BE, Le Marchand L, Ito H, Kasuga Y, Ahn SH, Kang HS, Chan KY, Iwata H, Tsugane S, Li C, Shu XO, Kang DH, Zheng W: Genome-wide association study in East Asians identifies novel susceptibility loci for breast cancer. PLoS Genet 2012, 8:e1002532.

108. Ghoussaini M, Fletcher O, Michailidou K, Turnbull C, Schmidt MK, Dicks E, Dennis J, Wang Q, Humphreys MK, Luccarini C, Baynes C, Conroy D, Maranian M, Ahmed S, Driver K, Johnson N, Orr N, Dos Santos Silva I, Waisfisz Q, Meijers-Heijboer H, Uitterlinden AG, Rivadeneira F, Netherlands Collaborative Group on Hereditary Breast and Ovarian Cancer (HEBON), Hall P, Czene K, Irwanto A, Liu J, Nevanlinna H, Aittomäki K, Blomqvist C, Meindl A, Schmutzler RK, Müller-Myhsok B, Lichtner P, Chang-Claude J, Hein R, Nickels S, Flesch-Janys D, et al: Genome-wide association analysis identifies three new breast cancer susceptibility loci. Nat Genet 2012, 44:312-318.

109. Siddiq A, Couch FJ, Chen GK, Lindström S, Eccles D, Millikan RC, Michailidou K, Stram DO, Beckmann L, Rhie SK, Ambrosone CB, Aittomäki K, Amiano P, Apicella C, Australian Breast Cancer Tissue Bank Investigators, Baglietto L, Bandera EV, Beckmann MW, Berg CD, Bernstein L, Blomqvist C, Brauch H, Brinton L, Bui QM, Buring JE, Buys SS, Campa D, Carpenter JE, Chasman DI, Chang-Claude J, et al: A meta-analysis of genome-wide association studies of breast cancer identifies two novel susceptibility loci at $6 q 14$ and 20q11. Hum Mol Genet 2012, 21:5373-5384.

110. Kim HC, Lee JY, Sung H, Choi JY, Park SK, Lee KM, Kim YJ, Go MJ, Li L, Cho YS, Park M, Kim DJ, Oh JH, Kim JW, Jeon JP, Jeon SY, Min H, Kim HM, Park J, Yoo KY, Noh DY, Ahn SH, Lee MH, Kim SW, Lee JW, Park BW, Park WY, Kim EH, Kim MK, Han W, Lee SA, Matsuo K, Shen CY, Wu PE, Hsiung CN, Lee JY, Kim HL, Han BG, Kang D: A genome-wide association study identifies a breast cancer risk variant in ERBB4 at 2q34: results from the Seoul Breast Cancer Study. Breast Cancer Res 2012, 14:R56.

111. Orr N, Lemnrau A, Cooke R, Fletcher O, Tomczyk K, Jones M, Johnson N, Lord CJ, Mitsopoulos C, Zvelebil M, McDade SS, Buck G, Blancher C, KConFab C, Trainer AH, James PA, Bojesen SE, Bokmand S, Nevanlinna H, Mattson J, Friedman E, Laitman Y, Palli D, Masala G, Zanna I, Ottini L, Giannini G, Hollestelle A, Ouweland AM, Novaković S, Krajc M, et al: Genome-wide association study identifies a common variant in RAD51B associated with male breast cancer risk. Nat Genet 2012, 44:1182-1184.

112. Elgazzar S, Zembutsu H, Takahashi A, Kubo M, Aki F, Hirata K, Takatsuka Y, Okazaki M, Ohsumi S, Yamakawa T, Sasa M, Katagiri T, Miki Y, Nakamura Y: A genome-wide association study identifies a genetic variant in the SIAH2 locus associated with hormonal receptor-positive breast cancer in Japanese. J Hum Genet 2012, 57:766-771.

113. Chen F, Chen GK, Stram DO, Millikan RC, Ambrosone CB, John EM, Bernstein L, Zheng W, Palmer JR, Hu JJ, Rebbeck TR, Ziegler RG, Nyante S, Bandera EV, Ingles SA, Press MF, Ruiz-Narvaez EA, Deming SL, Rodriguez-Gil JL, Demichele A, Chanock SJ, Blot W, Signorello L, Cai Q, Li G, Long J, Huo D, Zheng Y, Cox NJ, Olopade OI, Ogundiran TO, et al: A genome-wide association study of breast cancer in women of African ancestry. Hum Genet 2013, 132:39-48.

114. Bojesen SE, Pooley KA, Johnatty SE, Beesley J, Michailidou K, Tyrer JP, Edwards SL, Pickett HA, Shen HC, Smart CE, Hillman KM, Mai PL, Lawrenson K, Stutz MD, Lu Y, Karevan R, Woods N, Johnston RL, French JD, Chen X, Weischer M, Nielsen SF, Maranian MJ, Ghoussaini M, Ahmed S, Baynes C, Bolla MK, Wang Q, Dennis J, McGuffog L, Barrowdale D, et al: Multiple independent variants at the TERT locus are associated with telomere length and risks of breast and ovarian cancer. Nat Genet 2013, 45:371-384.

115. Garcia-Closas M, Couch FJ, Lindstrom S, Michailidou K, Schmidt MK, Brook MN, Orr N, Rhie SK, Riboli E, Feigelson HS, Le Marchand L, Buring JE, Eccles D, Miron P, Fasching PA, Brauch H, Chang-Claude J, Carpenter J, Godwin AK, Nevanlinna H, Giles GG, Cox A, Hopper JL, Bolla MK, Wang Q, Dennis J, Dicks E, Howat WJ, Schoof N, Bojesen SE, et al: Genome-wide association studies identify four ER negative-specific breast cancer risk loci. Nat Genet 2013, 45:392-398.

116. French JD, Ghoussaini M, Edwards SL, Meyer KB, Michailidou K, Ahmed S, Khan S, Maranian MJ, O'Reilly M, Hillman KM, Betts JA, Carroll T, Bailey PJ, Dicks E, Beesley J, Tyrer J, Maia AT, Beck A, Knoblauch NW, Chen C, Kraft P, Barnes D, González-Neira A, Alonso MR, Herrero D, Tessier DC, Vincent D, Bacot F, Luccarini C, Baynes C, Conroy D, et al: Functional Variants at the $11 q 13$ Risk Locus for Breast Cancer Regulate Cyclin D1 Expression through Long-Range Enhancers. Am J Hum Genet 2013, 92:489-503.

117. Couch FJ, Wang X, McGuffog L, Lee A, Olswold C, Kuchenbaecker KB, Soucy P, Fredericksen Z, Barrowdale D, Dennis J, Gaudet MM, Dicks E, Kosel M, Healey S, Sinilnikova OM, Lee A, Bacot F, Vincent D, Hogervorst FB, Peock S, Stoppa-Lyonnet D, Jakubowska A, Investigators K, Radice P, Schmutzler RK SWE-BRCA, Domchek SM, Piedmonte M, Singer CF, Friedman E, et al: Genome-Wide Association Study in BRCA1 Mutation Carriers Identifies Novel Loci Associated with Breast and Ovarian Cancer Risk. PLoS Genet 2013, 9:e1003212.

118. Gaudet MM, Kuchenbäcker KB, Vijai J, Klein RJ, Kirchhoff T, McGuffog L, Barrowdale D, Dunning AM, Lee A, Dennis J, Healey S, Dicks E, Soucy P, Sinilnikova OM, Pankratz VS, Wang X, Eldridge RC, Tessier DC, Vincent D, Bacot F, Hogervorst FB, Peock S, Stoppa-Lyonnet D, KConFab Investigators, Peterlongo P, Schmutzler RK, Nathanson KL, Piedmonte M, Singer CF, Thomassen M, et al: Identification of a BRCA2-Specific Modifier Locus at 6p24 Related to Breast Cancer Risk. PLoS Genet 2013, 9:e1003173.

119. Figueroa JD, Garcia-Closas M, Humphreys M, Platte R, Hopper JL, Southey MC, Apicella C, Hammet F, Schmidt MK, Broeks A, Tollenaar RA, Van't Veer $L_{\text {, }}$ Fasching PA, Beckmann MW, Ekici AB, Strick R, Peto J, dos Santos Silva I, Fletcher O, Johnson N, Sawyer E, Tomlinson I, Kerin M, Burwinkel B, Marme F, Schneeweiss A, Sohn C, Bojesen S, Flyger H, Nordestgaard BG, et al: Associations of common variants at 1p11.2 and 14q24.1 (RAD51L1) with breast cancer risk and heterogeneity by tumor subtype: findings from the Breast Cancer Association Consortium. Hum Mol Genet 2011, 20:4693-4706.

120. Jiang Y, Shen H, Liu X, Dai J, Jin G, Qin Z, Chen J, Wang S, Wang X, Hu Z, Shen $\mathrm{H}$ : Genetic variants at $1 \mathrm{p} 11.2$ and breast cancer risk: a two-stage study in Chinese women. PLoS One 2011, 6:e21563.

121. Cox A, Dunning AM, Garcia-Closas M, Balasubramanian S, Reed MW, Pooley KA, Scollen S, Baynes C, Ponder BA, Chanock S, Lissowska J, Brinton L, Peplonska B, Southey MC, Hopper JL, McCredie MR, Giles GG, Fletcher O, Johnson N, dos Santos Silva I, Gibson L, Bojesen SE, Nordestgaard BG, Axelsson CK, Torres D, Hamann U, Justenhoven C, Brauch H, Chang-Claude J, Kropp S, et al: Breast Cancer Association Consortium: A common coding variant in CASP8 is associated with breast cancer risk. Nat Genet 2007, 39:352-358.

122. Camp NJ, Parry M, Knight S, Abo R, Elliott G, Rigas SH, Balasubramanian SP, Reed MW, McBurney H, Latif A, Newman WG, Cannon-Albright LA, Evans DG, Cox A: Fine-mapping CASP8 risk variants in breast cancer. Cancer Epidemiol Biomarkers Prev 2012, 21:176-181.

123. Milne RL, Benítez J, Nevanlinna H, Heikkinen T, Aittomäki K, Blomqvist C, Arias Jl, Zamora MP, Burwinkel B, Bartram CR, Meindl A, Schmutzler RK, Cox A, Brock I, Elliott G, Reed MW, Southey MC, Smith L, Spurdle AB, Hopper JL, Couch FJ, Olson JE, Wang $X$, Fredericksen Z, Schürmann P, Bremer M, Hillemanns P, Dörk T, Devilee P, van Asperen CJ, Breast Cancer Association Consortium, et al: Risk of estrogen receptor-positive and -negative breast cancer and single-nucleotide polymorphism 2q35-rs13387042. J Natl Cancer Inst 2009, 101:1012-1018.

124. Li J, Humphreys K, Heikkinen T, Aittomäki K, Blomqvist C, Pharoah PD, Dunning AM, Ahmed S, Hooning MJ, Martens JW, van den Ouweland AM, 
Alfredsson L, Palotie A, Peltonen-Palotie L, Irwanto A, Low HQ, Teoh GH, Thalamuthu A, Easton DF, Nevanlinna H, Liu J, Czene K, Hall P: A combined analysis of genome-wide association studies in breast cancer. Breast Cancer Res Treat 2011, 126:717-727.

125. Stacey SN, Sulem P, Zanon C, Gudjonsson SA, Thorleifsson G, Helgason A, Jonasdottir A, Besenbacher S, Kostic JP, Fackenthal JD, Huo D, Adebamowo C, Ogundiran T, Olson JE, Fredericksen ZS, Wang X, Look MP, Sieuwerts AM, Martens JW, Pajares I, Garcia-Prats MD, Ramon-Cajal JM, de Juan A, Panadero A, Ortega E, Aben KK, Vermeulen SH, Asadzadeh F, van Engelenburg KC, Margolin S, Shen CY, et al: Ancestry-shift refinement mapping of the C6orf97-ESR1 breast cancer susceptibility locus. PLoS Genet 2010, 6:e1001029.

126. Han J, Jiang T, Bai H, Gu H, Dong J, Ma H, Hu Z, Shen H: Genetic variants of $6 \mathrm{q} 25$ and breast cancer susceptibility: a two-stage fine mapping study in a Chinese population. Breast Cancer Res Treat 2011, 129:901-907.

127. Hein R, Maranian M, Hopper JL, Kapuscinski MK, Southey MC, Park DJ, Schmidt MK, Broeks A, Hogervorst FB, Bueno-de-Mesquita HB, Muir KR, Lophatananon A, Rattanamongkongul S, Puttawibul P, Fasching PA, Hein A, Ekici AB, Beckmann MW, Fletcher O, Johnson N, dos Santos Silva I, Peto J, Sawyer E, Tomlinson I, Kerin M, Miller N, Marmee F, Schneeweiss A, Sohn C, Burwinkel B, et al: Comparison of $6 \mathrm{q} 25$ breast cancer hits from Asian and European Genome Wide Association Studies in the Breast Cancer Association Consortium (BCAC). PLoS One 2012, 7:e42380.

128. Kong A, Steinthorsdottir V, Masson G, Thorleifsson G, Sulem P, Besenbacher $\mathrm{S}$, Jonasdottir A, Sigurdsson A, Kristinsson KT, Jonasdottir A, Frigge ML, Gylfason A, Olason PI, Gudjonsson SA, Sverrisson S, Stacey SN, Sigurgeirsson $B$, Benediktsdottir KR, Sigurdsson $H$, Jonsson T, Benediktsson R, Olafsson $J H_{\text {, }}$ Johannsson OT, Hreidarsson AB, Sigurdsson G, DIAGRAM Consortium, Ferguson-Smith AC, Gudbjartsson DF, Thorsteinsdottir U, Stefansson K: Parental origin of sequence variants associated with complex diseases. Nature 2009, 462:868-874.

129. Stevens KN, Fredericksen Z, Vachon CM, Wang X, Margolin S, Lindblom A, Nevanlinna H, Greco D, Aittomäki K, Blomqvist C, Chang-Claude J, Vrieling A, Flesch-Janys D, Sinn HP, Wang-Gohrke S, Nickels S, Brauch H, Network GENICA, Ko YD, Fischer HP, Schmutzler RK, Meindl A, Bartram CR, Schott S, Engel C, Godwin AK, Weaver J, Pathak HB, Sharma P, Brenner H, et al: $19 p 13.1$ is a triple-negative-specific breast cancer susceptibility locus. Cancer Res 2012, 72:1795-1803.

130. Long J, Delahanty RJ, Li G, Gao YT, Lu W, Cai Q, Xiang YB, Li C, Ji BT, Zheng Y, Ali S, Shu XO, Zheng W: A Common Deletion in the APOBEC3 Genes and Breast Cancer Risk. J Natl Cancer Inst 2013, 105:573-579.

131. Meyer KB, Maia AT, O'Reilly M, Teschendorff AE, Chin SF, Caldas C, Ponder BA: Allele-specific up-regulation of FGFR2 increases susceptibility to breast cancer. PLoS Biol 2008, 6:e108.

132. Wang X, Pankratz VS, Fredericksen Z, Tarrell R, Karaus M, McGuffog L, Pharaoh PD, Ponder BA, Dunning AM, Peock S, Cook M, Oliver C, Frost D, EMBRACE, Sinilnikova OM, Stoppa-Lyonnet D, Mazoyer S, Houdayer C, GEMO, Hogervorst FB, Hooning MJ, Ligtenberg MJ, HEBON, Spurdle A, Chenevix-Trench G, kConFab, Schmutzler RK, Wappenschmidt B, Engel C, Meindl $A$, et al: Common variants associated with breast cancer in genome-wide association studies are modifiers of breast cancer risk in BRCA1 and BRCA2 mutation carriers. Hum Mol Genet 2010, 19:2886-2897.

133. Sakoda LC, Jorgensen E, Witte JS: Turning of COGS moves forward findings for hormonally mediated cancers. Nat Genet 2013, 45:345-348.

134. Bolton KL, Tyrer J, Song H, Ramus SJ, Notaridou M, Jones C, Sher T, Gentry-Maharaj A, Wozniak E, Tsai YY, Weidhaas J, Paik D, Van Den Berg DJ, Stram DO, Pearce CL, Wu AH, Brewster W, Anton-Culver H, Ziogas A, Narod SA, Levine DA, Kaye SB, Brown R, Paul J, Flanagan J, Sieh W, McGuire V, Whittemore AS, Campbell I, Gore ME, Lissowska J, et al: Common variants at 19 p13 are associated with susceptibility to ovarian cancer. Nat Genet 2010, 42:880-884.

135. Ghoussaini M, Song H, Koessler T, Al Olama AA, Kote-Jarai Z, Driver KE, Pooley KA, Ramus SJ, Kjaer SK, Hogdall E, DiCioccio RA, Whittemore AS, Gayther SA, Giles GG, Guy M, Edwards SM, Morrison J, Donovan JL, Hamdy FC, Dearnaley DP, Ardern-Jones AT, Hall AL, O'Brien LT, Gehr-Swain BN, Wilkinson RA, Brown PM, Hopper JL, Neal DE, Pharoah PD, Ponder BA, Eeles RA, Easton DF, Dunning AM, UK Genetic Prostate Cancer Study Collaborators/British Association of Urological Surgeons' Section of Oncology, UK ProtecT Study Collaborators: Multiple loci with different cancer specificities within the 8q24 gene desert. J Natl Cancer Inst 2008, 100:962-966.
136. Network CGA: Comprehensive molecular portraits of human breast tumours. Nature 2012, 490:61-70.

137. den Dekker AD, Xu X, Vaughn MD, Puckett AH, Gardner LL, Lambring CJ, Deschenes L, Samuelson DJ: Rat Mcs $1 \mathrm{~b}$ is concordant to the genome-wide association-identified breast cancer risk locus at human $5 q 11.2$ and MIER3 is a candidate cancer susceptibility gene. Cancer Res 2012, 72:6002-6012.

138. Li Q, Seo JH, Stranger B, McKenna A, Pe'er I, Laframboise T, Brown M, Tyekucheva S, Freedman ML: Integrative eQTL-based analyses reveal the biology of breast cancer risk loci. Cell 2013, 152:633-641.

139. Eriksson N, Benton GM, Do CB, Kiefer AK, Mountain JL, Hinds DA, Francke U, Tung JY: Genetic variants associated with breast size also influence breast cancer risk. BMC Med Genet 2012, 13:53.

140. Lindström S, Vachon CM, Li J, Varghese J, Thompson D, Warren R, Brown J, Leyland J, Audley T, Wareham NJ, Loos RJ, Paterson AD, Rommens J, Waggott D, Martin LJ, Scott CG, Pankratz VS, Hankinson SE, Hazra A, Hunter DJ, Hopper JL, Southey MC, Chanock SJ, Silva Idos S, Liu J, Eriksson L, Couch FJ, Stone J, Apicella C, Czene K, Kraft P, Hall P, Easton DF, Boyd NF, Tamimi RM: Common variants in ZNF365 are associated with both mammographic density and breast cancer risk. Nat Genet 2011, 43:185-187.

141. Vachon CM, Scott CG, Fasching PA, Hall P, Tamimi RM, Li J, Stone J, Apicella C, Odefrey F, Gierach GL, Jud SM, Heusinger K, Beckmann MW, Pollan M, Fernández-Navarro P, Gonzalez-Neira A, Benitez J, van Gils CH, Lokate M, Onland-Moret NC, Peeters PH, Brown J, Leyland J, Varghese JS, Easton DF, Thompson DJ, Luben RN, Warren RM, Wareham NJ, Loos RJ, et al: Common breast cancer susceptibility variants in LSP1 and RAD51L1 are associated with mammographic density measures that predict breast cancer risk. Cancer Epidemiol Biomarkers Prev 2012, 21:1156-1166.

142. Wang K, Li WD, Zhang CK, Wang Z, Glessner JT, Grant SF, Zhao H, Hakonarson H, Price RA: A genome-wide association study on obesity and obesity-related traits. PLoS One 2011, 6:e18939.

143. Wellcome Trust Case Control Consortium: Genome-wide association study of CNVs in 16,000 cases of eight common diseases and 3,000 shared controls. Nature 2010, 464:713-720.

144. Nik-Zainal S, Alexandrov LB, Wedge DC, Van Loo P, Greenman CD, Raine K, Jones D, Hinton J, Marshall J, Stebbings LA, Menzies A, Martin S, Leung K, Chen L, Leroy C, Ramakrishna M, Rance R, Lau KW, Mudie L, Varela I, McBride DJ, Bignell GR, Cooke SL, Shlien A, Gamble J, Whitmore I, Maddison M, Tarpey PS, Davies HR, Papaemmanuil E, Stephens PJ, Breast Cancer Working Group of the International Cancer Genome Consortium, et al: Mutational processes molding the genomes of 21 breast cancers. Cell 2012, 149:979-993.

145. Burns MB, Lackey L, Carpenter MA, Rathore A, Land AM, Leonard B, Refsland EW, Kotandeniya D, Tretyakova N, Nikas JB, Yee D, Temiz NA, Donohue DE, McDougle RM, Brown WL, Law EK, Harris RS: APOBEC3B is an enzymatic source of mutation in breast cancer. Nature 2013, 494:366-370.

146. Krepischi AC, Achatz MI, Santos EM, Costa SS, Lisboa BC, Brentani H, Santos TM, Gonçalves A, Nóbrega AF, Pearson PL, Vianna-Morgante AM, Carraro DM, Brentani RR, Rosenberg C: Germline DNA copy number variation in familial and early-onset breast cancer. Breast Cancer Res 2012, 14:R24.

147. Pylkäs K, Vuorela M, Otsukka M, Kallioniemi A, Jukkola-Vuorinen A, Winqvist R: Rare copy number variants observed in hereditary breast cancer cases disrupt genes in estrogen signaling and TP53 tumor suppression network. PLOS Genet 2012, 8:e1002734.

148. Pharoah PD, Antoniou AC, Easton DF, Ponder BA: Polygenes, risk prediction, and targeted prevention of breast cancer. N Engl J Med 2008 358:2796-2803.

149. Pashayan N, Duffy SW, Chowdhury S, Dent T, Burton H, Neal DE, Easton DF, Eeles R, Pharoah P: Polygenic susceptibility to prostate and breast cancer: implications for personalised screening. Br J Cancer 2011, 104:1656-1663.

150. Burton H, Chowdhury S, Dent T, Hall A, Pashayan N, Pharoah P: Public health implications from COGS and potential for risk stratification and screening. Nat Genet 2013, 45:349-351.

151. Robertson L, Hanson H, Seal S, Warren-Perry M, Hughes D, Howell I, Turnbull C, Houlston R, Shanley S, Butler S, Evans DG, Ross G, Eccles D, Tutt A, Rahman $\mathrm{N}$ : BRCA1 testing should be offered to individuals with triple-negative breast cancer diagnosed below 50 years. Br J Cancer 2012, 106:1234-1238.

152. Broeks A, Schmidt MK, Sherman ME, Couch FJ, Hopper JL, Dite GS, Apicella C, Smith LD, Hammet F, Southey MC, Veer LJ V 't, de Groot R, Smit VT, 
Fasching PA, Beckmann MW, Jud S, Ekici AB, Hartmann A, Hein A, Schulz-Wendtland R, Burwinkel B, Marme F, Schneeweiss A, Sinn HP, Sohn C, Tchatchou S, Bojesen SE, Nordestgaard BG, Flyger H, Ørsted DD, Kaur-Knudsen D, Milne RL, et al: Low penetrance breast cancer susceptibility loci are associated with specific breast tumor subtypes: findings from the Breast Cancer Association Consortium. Hum Mol Genet 2011, 20:3289-3303.

153. Fasching PA, Pharoah PD, Cox A, Nevanlinna H, Bojesen SE, Karn T, Broeks A, van Leeuwen FE, van't Veer LJ, Udo R, Dunning AM, Greco D, Aittomäki K, Blomqvist C, Shah M, Nordestgaard BG, Flyger H, Hopper JL, Southey MC, Apicella C, Garcia-Closas M, Sherman M, Lissowska J, Seynaeve C, Huijts PE, Tollenaar RA, Ziogas A, Ekici AB, Rauh C, Mannermaa A, et al: The role of genetic breast cancer susceptibility variants as prognostic factors. Hum Mol Genet 2012, 21:3926-3939.

154. Hynes NE, Dey JH: Potential for targeting the fibroblast growth factor receptors in breast cancer. Cancer Res 2010, 70:5199-5202.

155. Stevens KN, Vachon CM, Couch FJ: Genetic Susceptibility to Triple-Negative Breast Cancer. Cancer Res 2013, 73:2025-2030.

156. Dedes KJ, Wilkerson PM, Wetterskog D, Weigelt B, Ashworth A, Reis-Filho JS: Synthetic lethality of PARP inhibition in cancers lacking BRCA1 and BRCA2 mutations. Cell Cycle 2011, 10:1192-1199.

157. Eich M, Ross WP, Dianov GL, Digweed M, Kaina B: Nijmegen Breakage Syndrome protein (NBN) causes resistance to methylating anticancer drugs suc as temozolomide. Mol Pharmacol 2010, 78:943-951.

158. Reaper PM, Griffiths MR, Long JM, Charrier JD, Maccormick S, Charlton PA, Golec JM, Pollard JR: Selective killing of ATM- or p53-deficient cancer cells through inhibition of ATR. Nat Chem Biol 2011, 7:428-430.

doi:10.1186/1897-4287-11-12

Cite this article as: Bogdanova et al.: Hereditary breast cancer: ever more pieces to the polygenic puzzle. Hereditary Cancer in Clinical Practice 2013 11:12.

\section{Submit your next manuscript to BioMed Central and take full advantage of:}

- Convenient online submission

- Thorough peer review

- No space constraints or color figure charges

- Immediate publication on acceptance

- Inclusion in PubMed, CAS, Scopus and Google Scholar

- Research which is freely available for redistribution 